\title{
Repurposing of drugs for triple negative breast cancer: an overview
}

\author{
Andrea Spini ${ }^{1,2}$, Sandra Donnini ${ }^{3}$, Pan Pantziarka ${ }^{4}$, Sergio Crispino ${ }^{4,5}$ and Marina Ziche ${ }^{1}$ \\ ${ }^{1}$ Department of Medicine, Surgery and Neuroscience, University of Siena, Siena 53100, Italy \\ 2Service de Pharmacologie Médicale, INSERM U1219, University of Bordeaux, Bordeaux 33000, France \\ ${ }^{3}$ Department of Life Sciences, University of Siena, Siena 53100, Italy \\ ${ }^{4}$ Anticancer Fund, Strombeek Bever 1853, Belgium \\ ${ }^{5}$ ASSO, Siena, Italy
}

\section{Abstract}

Breast cancer $(\mathrm{BC})$ is the most frequent cancer among women in the world and it remains a leading cause of cancer death in women globally. Among BCs, triple negative breast cancer (TNBC) is the most aggressive, and for its histochemical and molecular characteristics is also the one whose therapeutic opportunities are most limited. The REpurposing Drugs in Oncology (ReDO) project investigates the potential use of off patent non-cancer drugs as sources of new cancer therapies. Repurposing of old non-cancer drugs, clinically approved, off patent and with known targets into oncological indications, offers potentially cheaper effective and safe drugs. In line with this project, this article describes a comprehensive overview of preclinical or clinical evidence of drugs included in the ReDO database and/or PubMed for repurposing as anticancer drugs into TNBC therapeutic treatments.

Keywords: triple negative breast cancer, repositioning, non-cancer drug, preclinical studies, clinical studies

\section{Background}

Breast cancer $(\mathrm{BC})$ is the most frequent cancer among women in the world. Triple negative breast cancer (TNBC) is a type of BC that does not express oestrogen receptors, progesterone receptors and epidermal growth factor receptors-2/Neu (HER2) and accounts for the $16 \%$ of BCs approximatively $[1,2]$. Due to its lack of response to hormone and targeted therapies, the number of therapeutic opportunities is limited [3, 4]. TNBC patients are difficult to treat, with unfavourable prognosis and are generally administered with the standard chemotherapy. At the moment, novel treatment approaches, such as immunotherapy, as well the repurposing of old drugs currently used for indications other than TNBC, is under investigation. In this context, we have previously reviewed the preclinical and clinical anticancer efficacy and safety of beta blockers in TNBC [5].

Drug repurposing is the application of an old drug to a new disease indication: this holds the promise of rapid clinical impact at a lower cost than de novo drug development [6]. In oncology, where new treatments in the last years are becoming more expensive due to the introduction of innovative therapies such as targeted therapies and immunotherapies,

Correspondence to: Marina Ziche Email: marina.ziche@unisi.it

ecancer 2020, 14:1071 https://doi.org/10.3332/ecancer.2020.1071

Published: $13 / 07 / 2020$ Received: 12/02/2020

Publication costs for this article were supported by ecancer (UK Charity number 1176307).

Copyright: (c) the authors; licensee ecancermedicalscience. This is an Open Access article distributed under the terms of the Creative Commons Attribution License (http:// creativecommons.org/licenses/by/3.0), which permits unrestricted use, distribution, and reproduction in any medium, provided the original work is properly cited. 
there is an increased interest at the use of already clinically approved non-cancer drugs, off patent and with known targets, as possible cancer treatments [7]. One study published by Pantziarka et al [8], point the spotlight on this matter building up a project about drug repurposing in the treatment of cancer. The REpurposing Drugs in Oncology (ReDO) project investigates the potential use of licensed non-cancer medications as sources of new cancer strategies. ReDO project has used a literature-based approach to identify licensed non-cancer drugs with published evidence of anticancer activity. At present, data of 268 drugs have been included in the REDO database (ReDO_DB) [8].

In line with this project, we searched in PubMed for published preclinical or clinical evidence of anticancer activity for all drugs included in the ReDO_DB for TNBC. Specifically, starting from each drug present in ReDO_DB, we searched in PubMed for published preclinical and clinical evidence of anticancer activity for TNBC. The strings were composed by the name of the drugs and specific keywords related to TNBC.

An additional search string was used to investigate potential clinical evidence about drugs not included in ReDO_DB or references not retrieved in the first search. The string was composed by three blocks concerning keywords related to TNBC, repurposing and study type, respectively. Both strings are provided in the supplementary file (Table S1). Observational or clinical trials for which a TNBC cohort was defined were included. The articles that were not written in English were excluded.

Moreover, clinicaltrials.gov [9] was searched for ongoing or completed clinical studies on drug repurposing and TNBC. All searches were performed on March 2019, and the information extracted were the following: 1) preclinical studies: number of studies per drug and pharmacological activity; 2) clinical studies: study type, country, study period, population studies, exclusion criteria, age, follow up, arms, treatments and outcomes; 3) clinicaltrials.gov: number of studies per drug.

The aim of this paper is to give to clinicians and scientists a comprehensive overview about preclinical and clinical studies, including clinical trials, present in literature on the repurposing of old-licensed drugs for TNBC.

We found 188 preclinical studies references (see Supplementary Material), 18 clinical references [10-26] and 16 references on clinical trials. gov on drug repurposing for TNBC [9].

\section{Preclinical studies}

Using the PubMed database, we found preclinical evidence on TNBC models (cell lines and xenograft models of TNBC) for 84 out of 268 old drugs (31.3\%) present in the ReDO_DB. For 42 of the 84 drugs, only one reference was retrieved (Table S2). Thirteen studies referred to the anti-proliferative, pro-apoptotic and immune-stimulating effects of metformin, thirteen to the cytotoxic and anti-metastatic effects of chloroquine, eleven to the anti-proliferative and anti-invasive effects of simvastatin, eight to the anti-inflammatory and anti-angiogenic effects of acid acetylsalicylic and eight studies to the anti-angiogenic, anti-proliferative and anti-apoptotic effects of zoledronic acid. Main indications for drugs with preclinical evidence of efficacy on TNBC model were various and heterogeneous including epilepsy, analgesia, hypertension, diabetes, insomnia and other.

\section{Clinical studies}

Table 1 shows all 17 clinical references collected (the article of Spera et al analyses two different retrospective studies on beta blockers efficacy and safety on TNBC [13], and the articles of Hagasewa et al [15] and Ishikawa et al [16] analysed the same cohort of patients). Clinical evidence on twelve licensed drugs was found, and of these drugs, eleven out of 268 (4.1\%) were included in ReDO_DB. Eleven studies out of 18 were retrospective studies [10-13,17, 19, 20, 22, 25, 26], six were phase II and [14-16, 18, 21, 23] one was a phase I clinical trial [24] (see Figure 1 for more details). Retrospective studies ranged from 1995 to 2016, and six out of eleven studies analysed a USA cohort of patients $[10,12,19,20,25,26]$. Eight studies were performed using medical records [10,12, 17, 19, 20, 22, 25, 26], one was based on disease registries [11] and two reported the results of previous clinical trials [13]. Of the 18 clinical studies collected, four analysed the efficacy of beta blockers (BB) [11-13], five of non-steroidal anti-inflammatory drugs (NSAIDs) [17-21], two of zoledronic acid [15, 16], one of metformin [10], one of tetramolybdate [14], one of itraconazole [22], one of esomeprazole [23], one of mifepristone [24] and two of statins [25, 26]. Outcomes retrieved from clinical studies were grouped, whenever possible, in pharmacological categories and summarised in Table 2. 


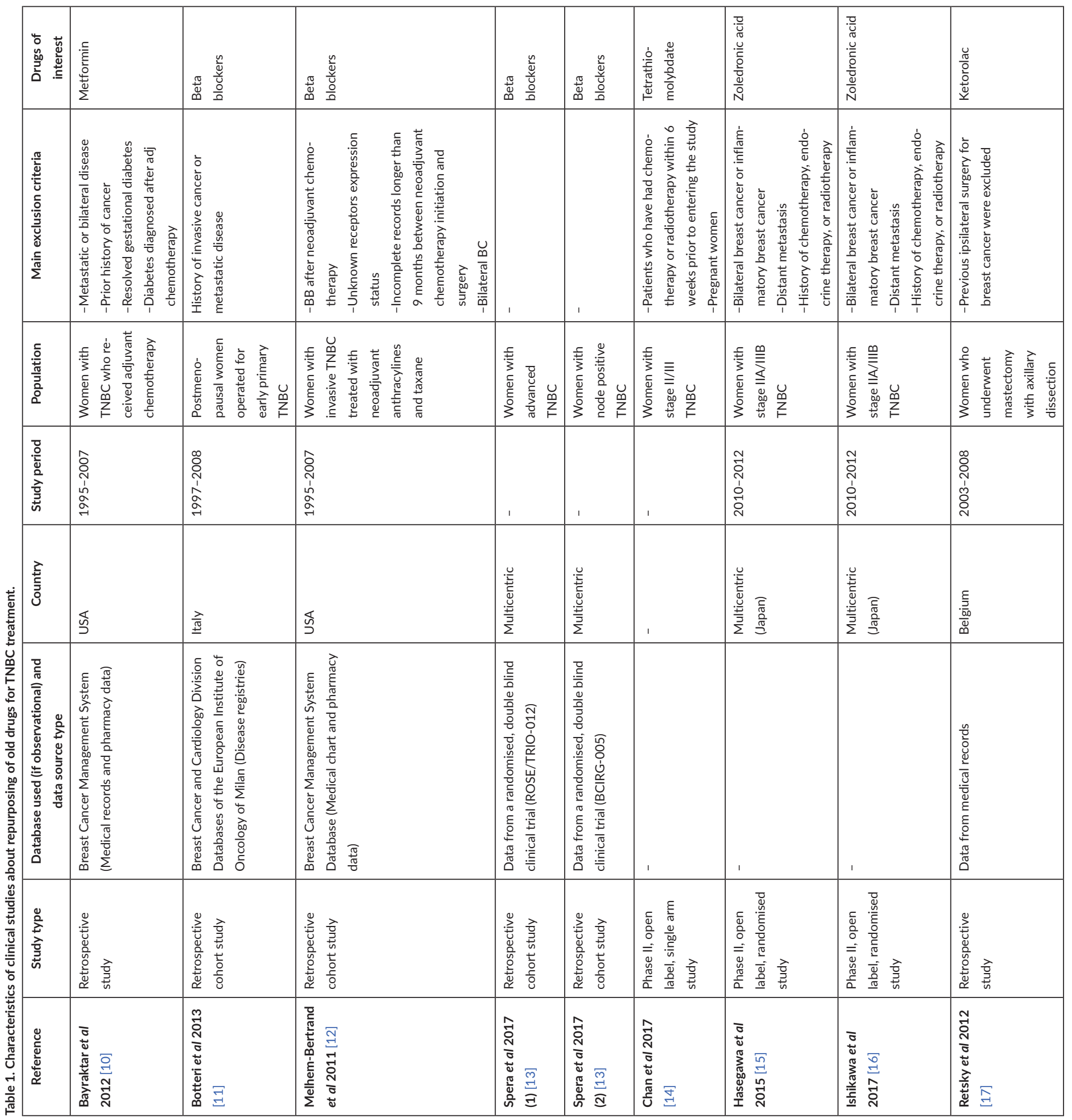




\begin{tabular}{|c|c|c|c|c|c|c|c|c|}
\hline 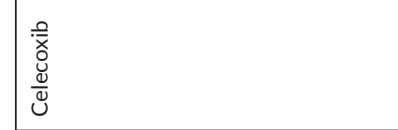 & 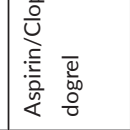 & 毫 & 粞 & 童 & 密 & 竟 & 爰 & 鄯 \\
\hline 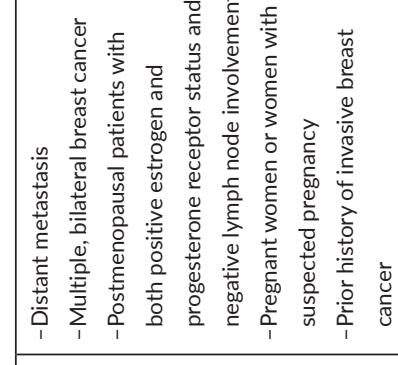 & 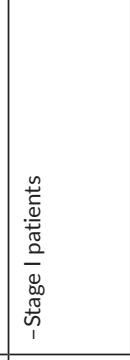 & 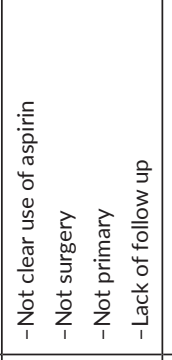 & & 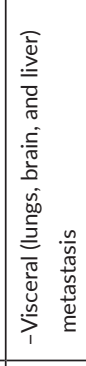 & 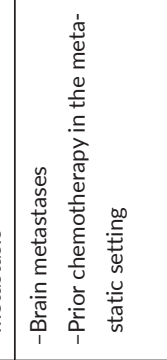 & 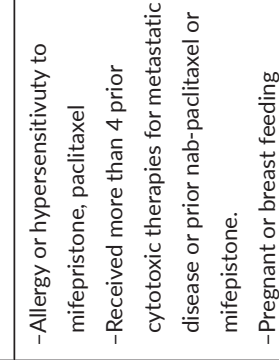 & 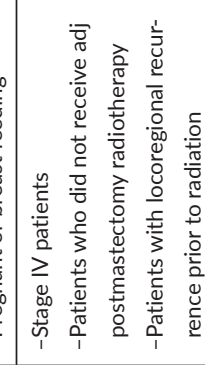 & \\
\hline 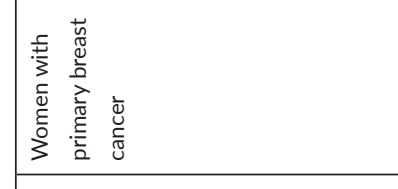 & 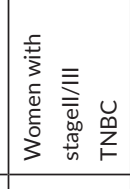 & 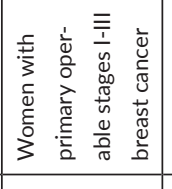 & 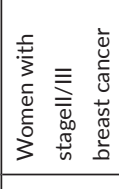 & 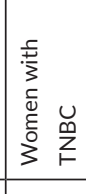 & 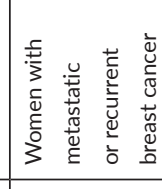 & 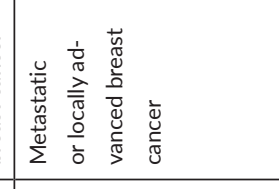 & 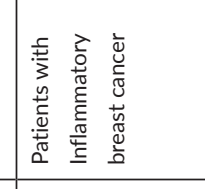 & 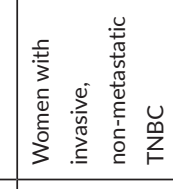 \\
\hline 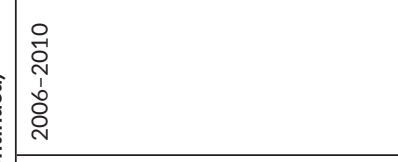 & 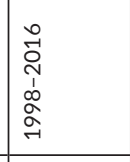 & 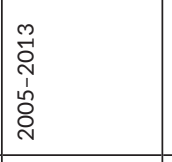 & 密 & 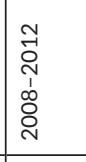 & &. & 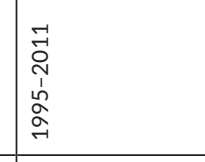 & 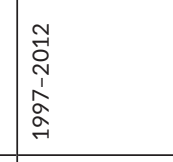 \\
\hline & 离 & 念 & & 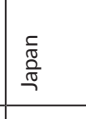 & & 离 & 离 & 箵 \\
\hline & 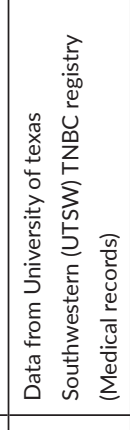 & & & 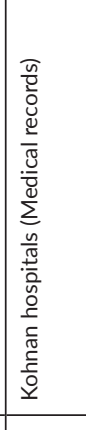 & & I & 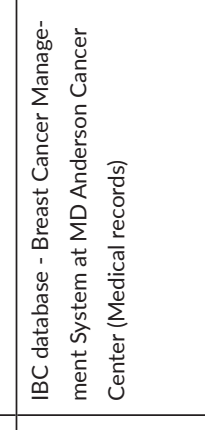 & 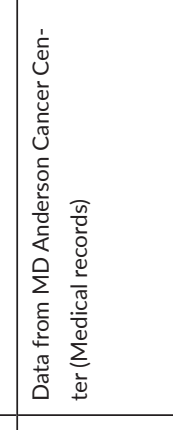 \\
\hline 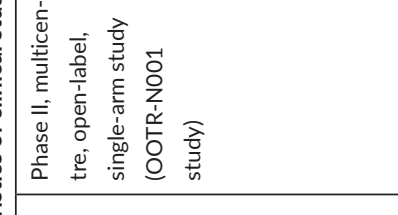 & 总 & 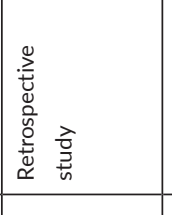 & 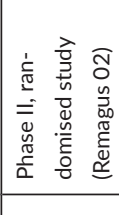 & 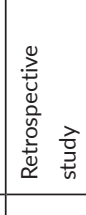 & 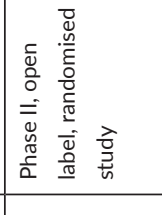 & 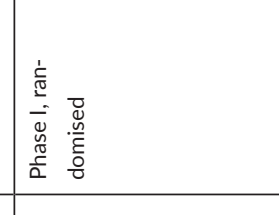 & 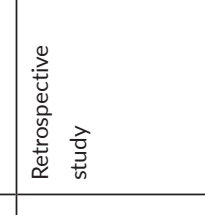 & 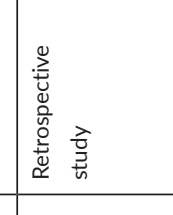 \\
\hline 施 & 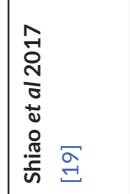 & $\mid$ & 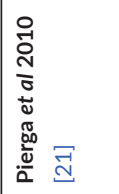 & 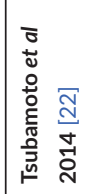 & 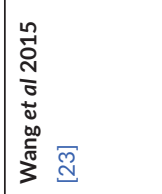 & 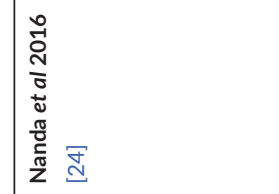 & 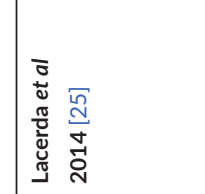 & 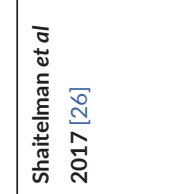 \\
\hline
\end{tabular}




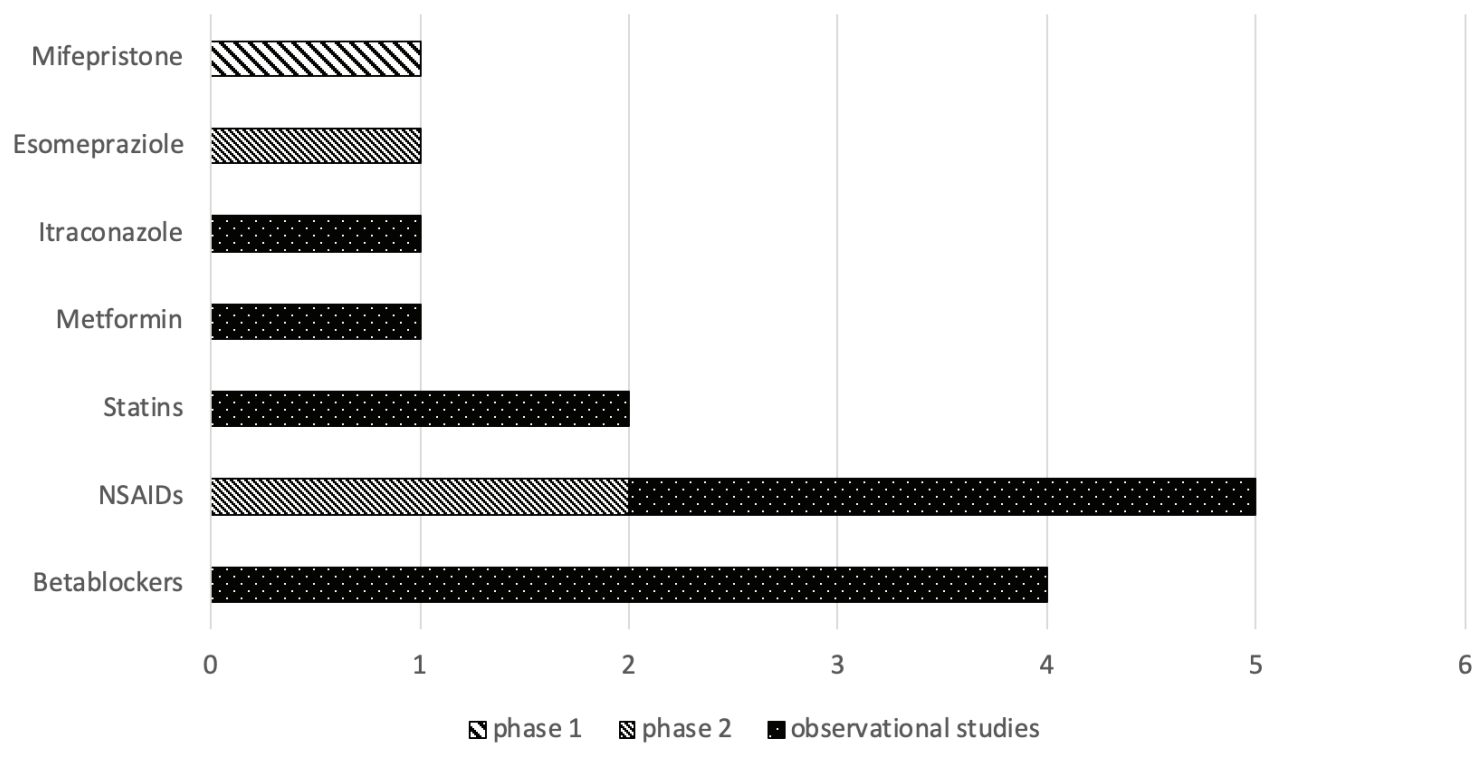

Figure 1. Type of studies per drug. This shows the number of clinical trials (only phase 1 and 2 studies were found) and observational studies conducted per drug/pharmacological classes.

\section{Beta blockers (BBs)}

BBs were evaluated on postmenopausal women with operated early primary TNBC, on women with invasive TNBC (receiving neoadjuvant chemotherapy), and on women with advanced or nodal positive TNBC. Study populations ranged from 35 patients to 1,417 patients. In the study of Melhem-Bertrandt et al [12], using medical chart and pharmacy data from the Breast Cancer Management System Database in the USA, women with invasive TNBC receiving neoadjuvant chemotherapy plus BBs were compared to patients receiving only neoadjuvant chemotherapy between 1995 and 2007. Hazard ratio of recurrence free survival for women administered with chemotherapy plus BBs was 0.30 (95\% Cl, 0.10-0.87; $p=0.027)$ and hazard ratio of overall survival was $0.35(95 \% \mathrm{Cl}, 0.12-1.00 ; p=0.05)$ [12]. Also, in the retrospective study of Botteri et al [11] using Breast Cancer and Cardiology Division Databases in Italy and analysing 800 postmenopausal women diagnosed and operated for early primary TNBC between 1997 and 2008, BB users showed significant benefit when compared to not BB users. Breast cancer related events where lower in BB users (13.6\% versus $27.9 \% ; p=0.02)$ and hazard ratio of metastasis and BC death were significant (0.32: $95 \% \mathrm{Cl} 0.12-0.90 ; p=0.031 ; 0.42: 95 \% \mathrm{Cl} 0.18-0.97 ; p=0.042$, respectively). The study of Spera et al [13], using data of a randomised, double blind clinical trial (ROSE/TRIO-012), showed significant benefit in women with advanced TNBC using BBs when compared to not users about progression free survival (Hazard ratio $=0.52 ; 95 \% \mathrm{Cl}, 0.34-0.80 ; p=0.002$ ) but not in overall survival (Hazard ratio $=0.87 ; 95 \% \mathrm{Cl} 0.58-1.31 ; p=0.504)$. The second study presented by Spera et al [13] using also data from another randomised, double blind clinical trial (BCIRG-005) about women with node positive TNBC did not show any significant benefit of relapse free survival and overall survival (Hazard ratio $=0.69 ; 95 \% \mathrm{Cl}, 0.35-1.34 ; p=0.269 ; 0.73 ; 95 \% \mathrm{Cl}, 0.35-1.48 ; p=0.38$, respectively). 


\begin{tabular}{|c|c|c|c|c|c|}
\hline 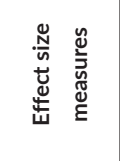 & 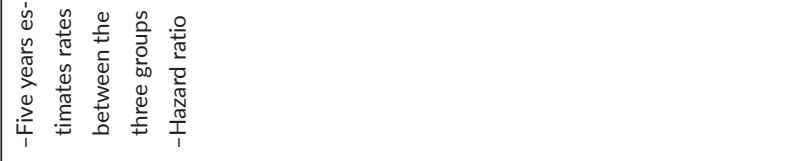 & 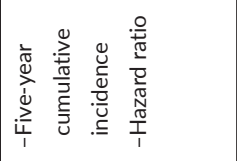 & 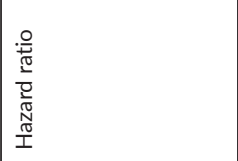 & 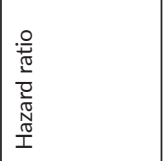 & 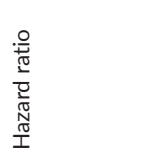 \\
\hline 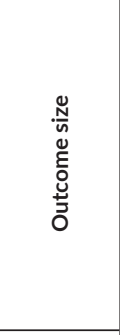 & 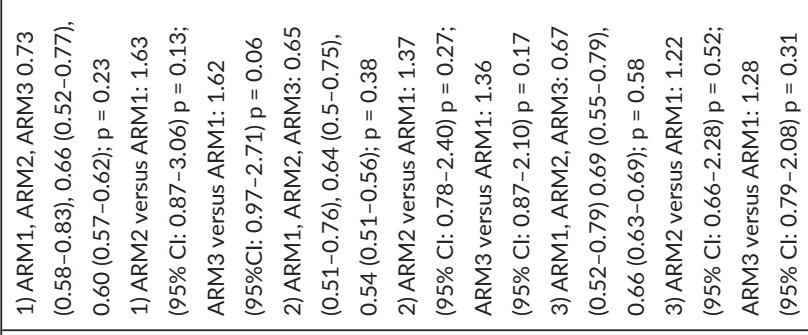 & 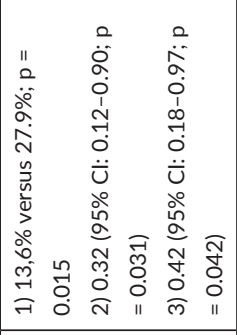 & 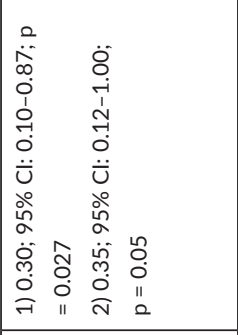 & 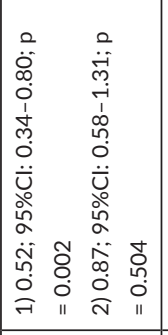 & 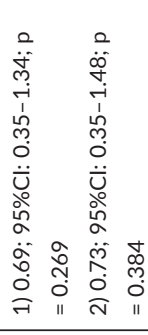 \\
\hline 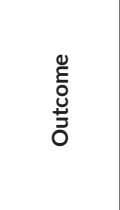 & 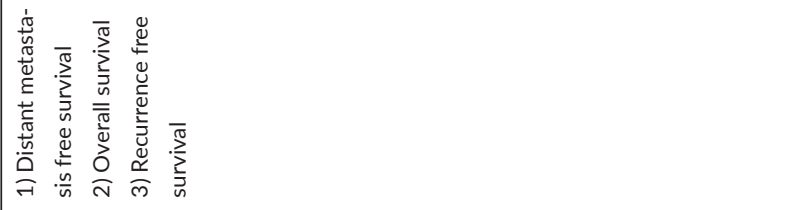 & 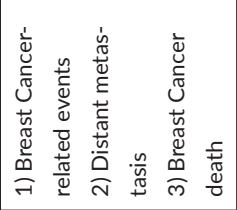 & 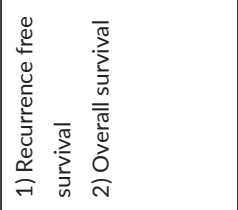 & 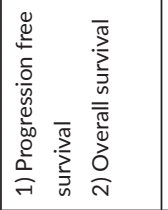 & 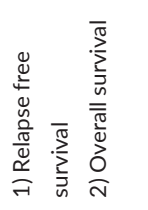 \\
\hline 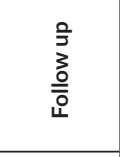 & 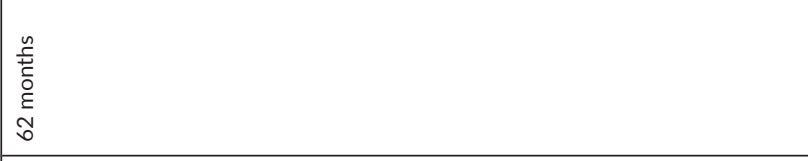 & 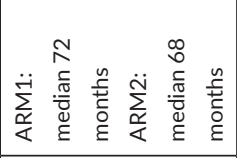 & 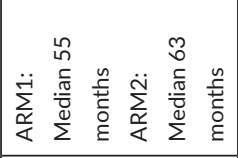 & 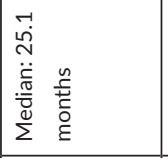 & 1 \\
\hline 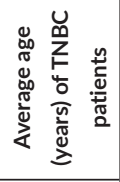 & 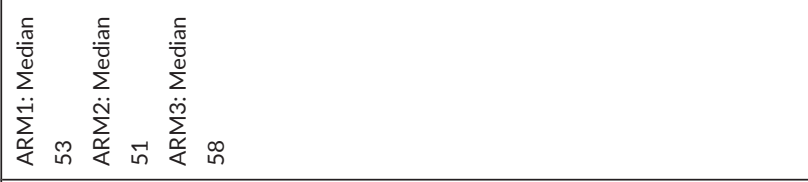 & 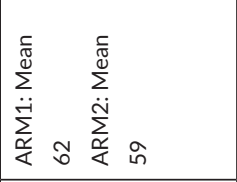 & 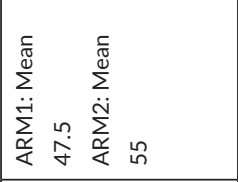 & 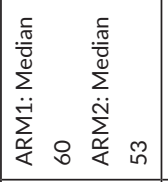 & 1 \\
\hline 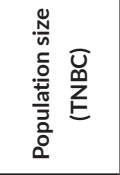 & 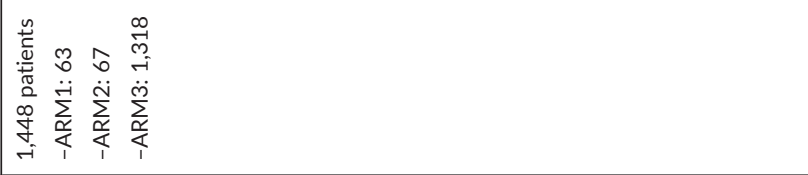 & 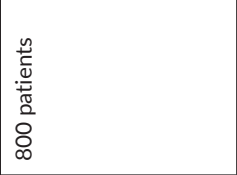 & 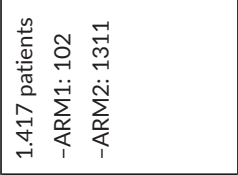 & 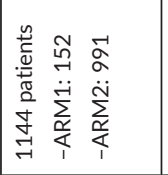 & 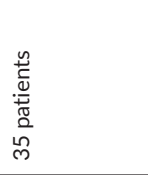 \\
\hline$\sum_{\substack{\alpha \\
<}}^{M}$ & 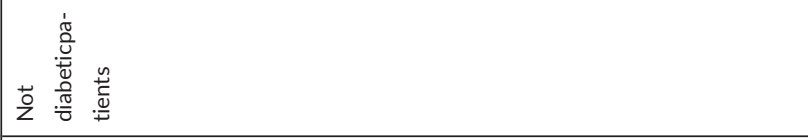 & I & 1 & 1 & 1 \\
\hline$\sum_{\frac{\alpha}{\alpha}}^{N}$ & 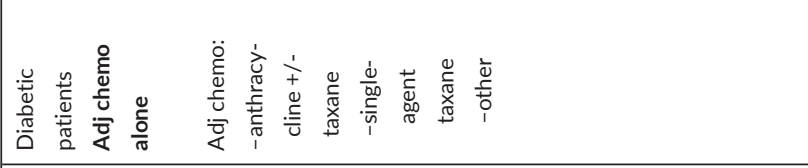 & 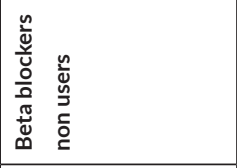 & 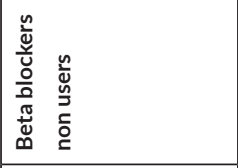 & 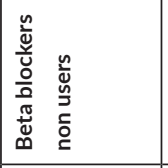 & 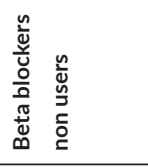 \\
\hline$\sum_{\frac{\alpha}{<}}^{+r}$ & 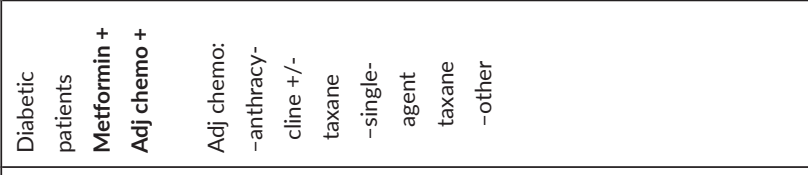 & 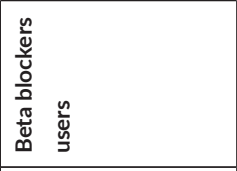 & 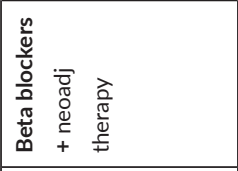 & 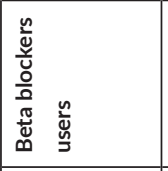 & 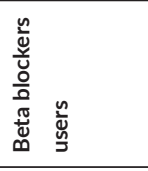 \\
\hline 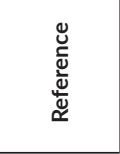 & 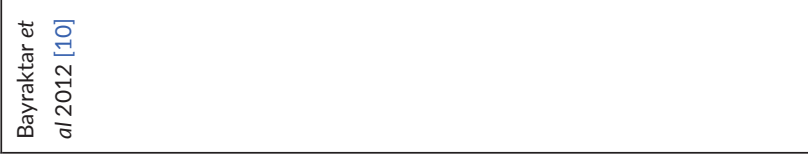 & 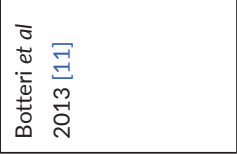 & 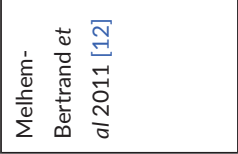 & 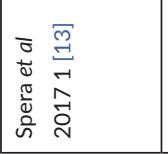 & 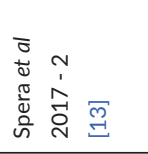 \\
\hline
\end{tabular}




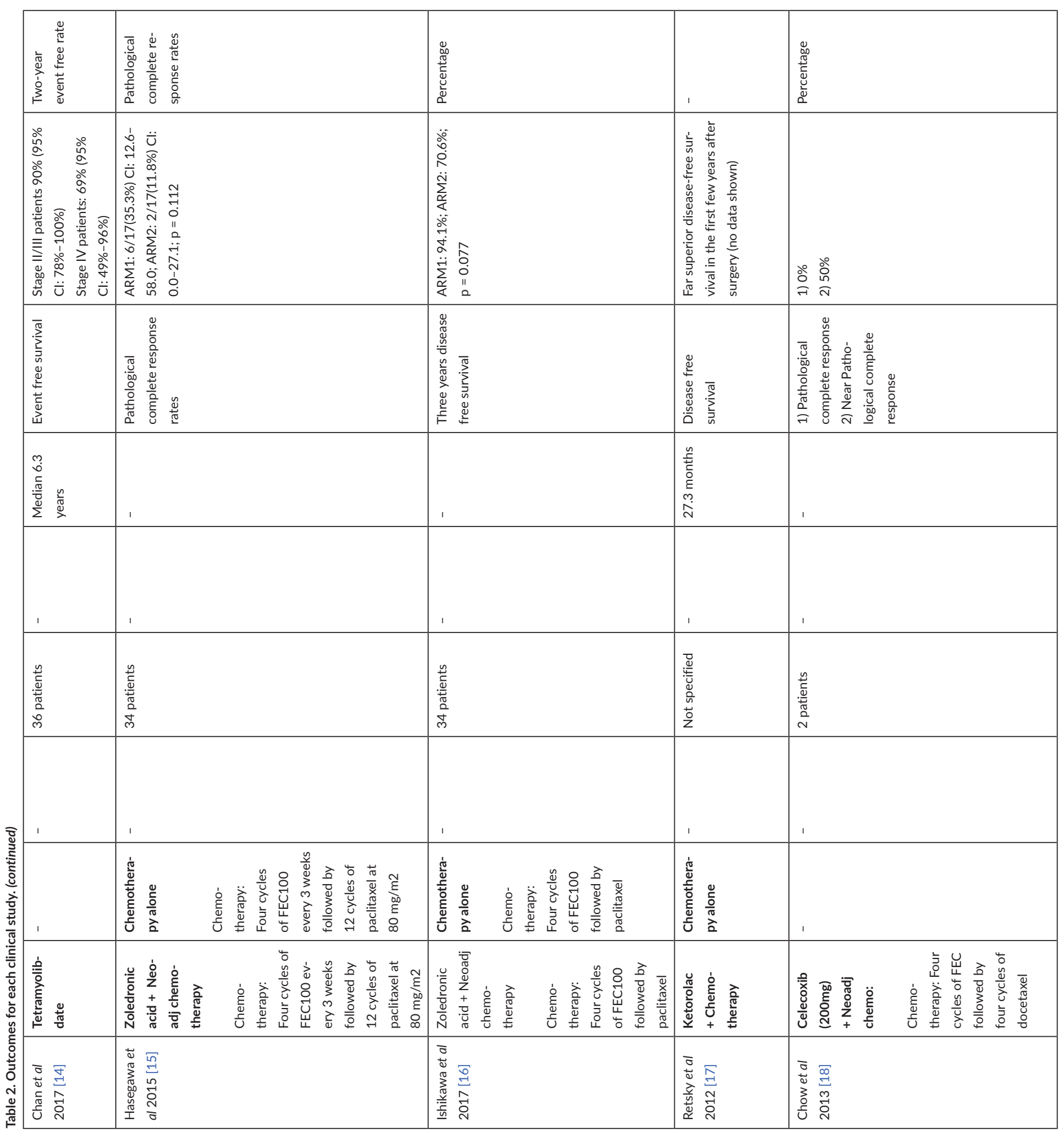




\begin{tabular}{|c|c|c|c|c|}
\hline 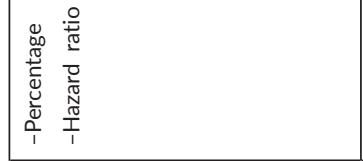 & 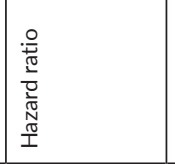 & 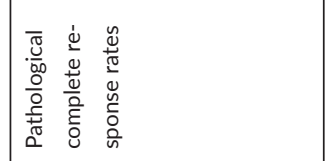 & 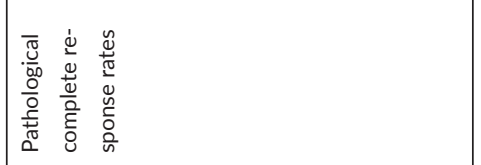 & 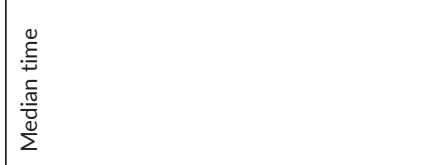 \\
\hline 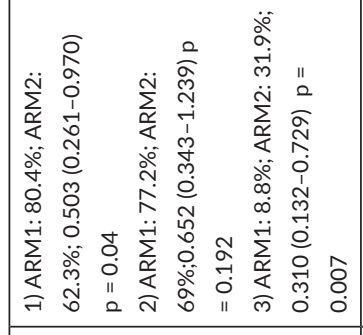 & 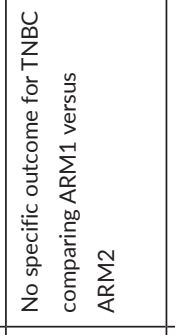 & 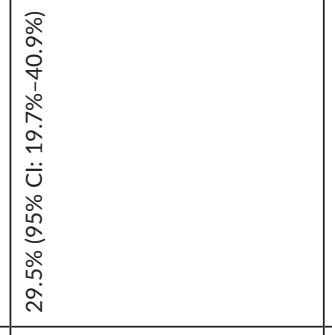 & 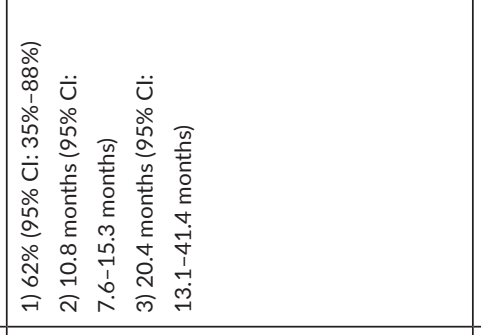 & 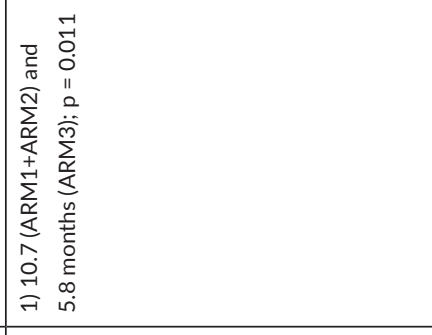 \\
\hline 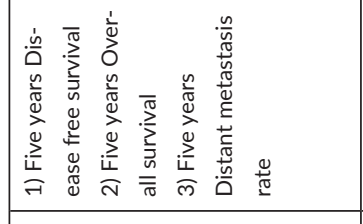 & 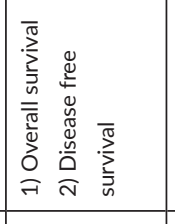 & 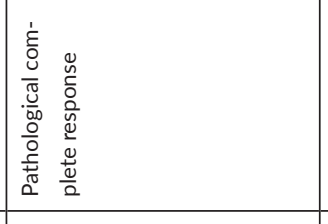 & 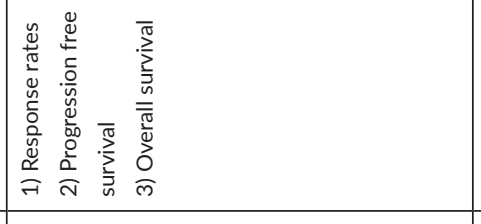 & 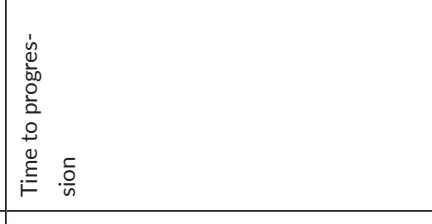 \\
\hline 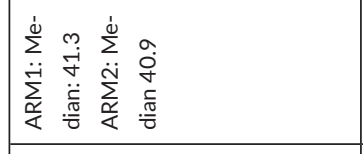 & 1 & 1 & 1 & 1 \\
\hline 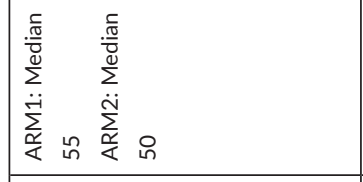 & 1 & 1 & 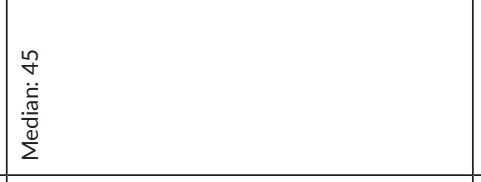 & 1 \\
\hline 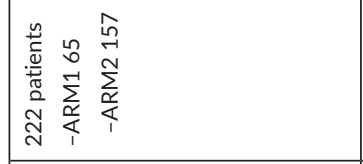 & 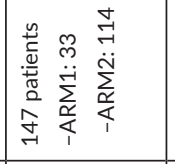 & 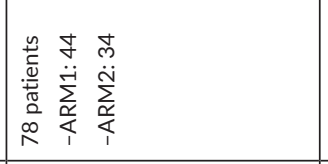 & 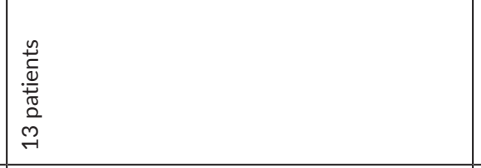 & 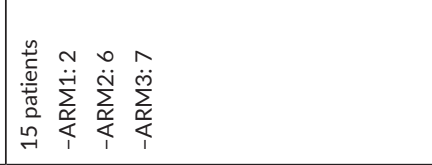 \\
\hline & 1 & 1 & 1 & 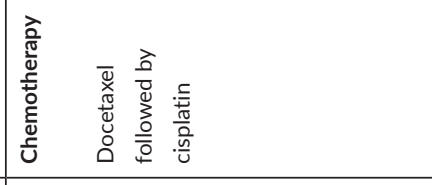 \\
\hline 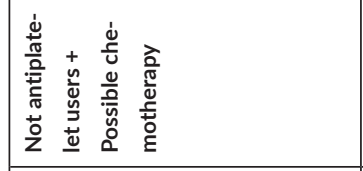 & 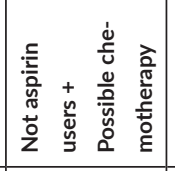 & 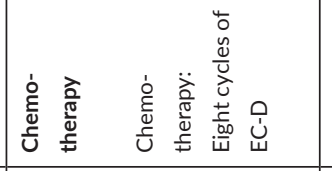 & & 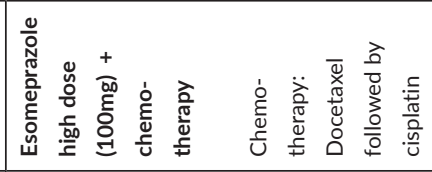 \\
\hline 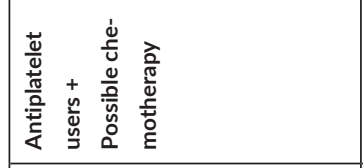 & 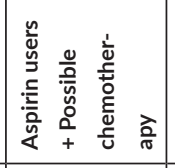 & 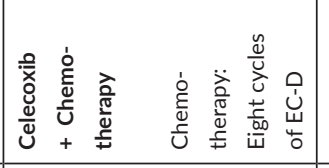 & 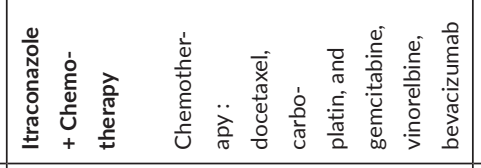 & 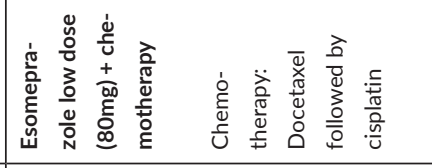 \\
\hline 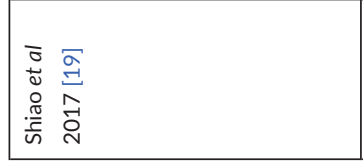 & 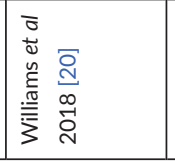 & 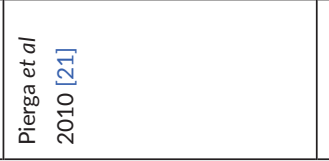 & 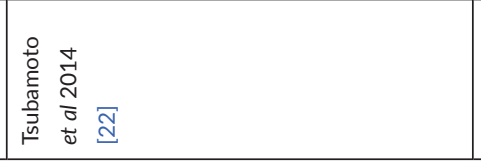 & 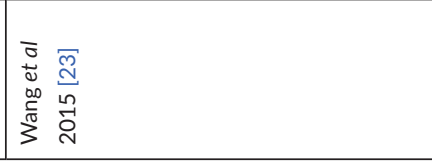 \\
\hline
\end{tabular}




\begin{tabular}{|c|c|c|c|}
\hline , & , & 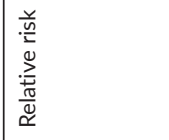 & \\
\hline 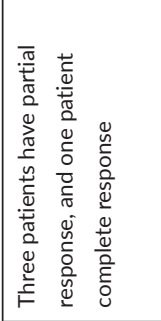 & 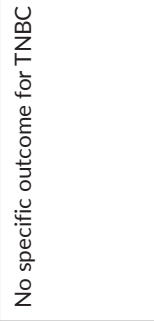 & 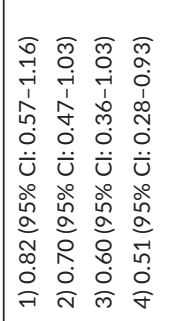 & \\
\hline 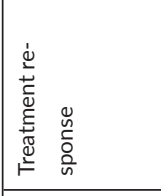 & 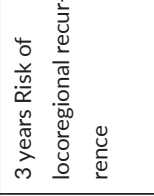 & 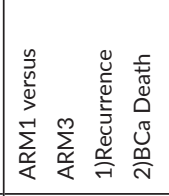 & 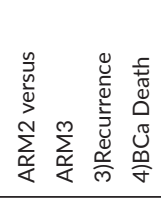 \\
\hline 1 & 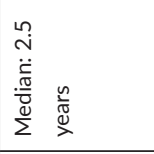 & 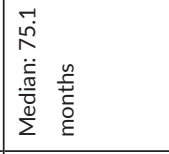 & \\
\hline 1 & 1 & 1 & \\
\hline 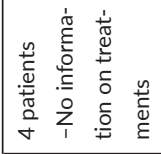 & 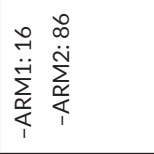 & 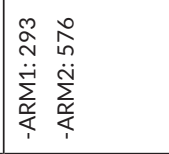 & \\
\hline $\begin{array}{l}\stackrel{\circ}{\stackrel{8}{0}} \\
\frac{\pi}{\alpha}\end{array}$ & 1 & 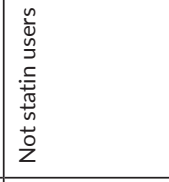 & \\
\hline 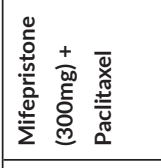 & 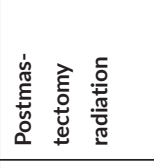 & 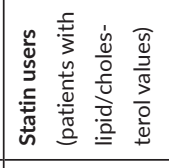 & \\
\hline 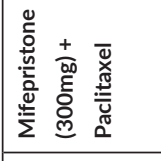 & 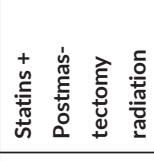 & 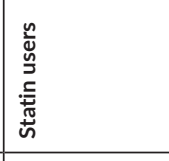 & \\
\hline 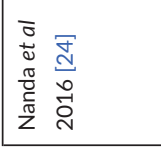 & 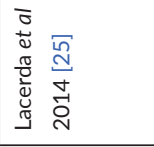 & 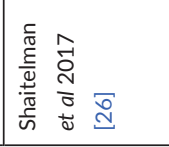 & \\
\hline
\end{tabular}

\section{Metformin}

The retrospective study of Bayraktar et al [10] using medical chart and pharmacy data from the Breast Cancer Management System Database compared women who received adjuvant chemotherapy with or without metformin in the USA between 1995 and 2007. In total, 1,448 patients (63 diabetic patients receiving metformin, 67 diabetic patients not receiving metformin and 1318 not diabetic patients). The 5 years survival estimates for distant metastasis free survival were $73 \%$ in the metformin group, $66 \%$ in the nonmetformin group and $60 \%$ in the non-diabetic group $(p=0.23)$. Overall survival was $67 \%$ in the metformin group, $69 \%$ in the non-metformin group and $66 \%$ in the non-diabetic group ( $p=0.58$ ). Recurrence free survival was $65 \%$ in the metformin group, $64 \%$ in the non-metformin group and $54 \%$ in the non-diabetic group (0.38). Also, after adjustments, no significant survival outcomes were obtained.

\section{Tetramolybdate}

The primary endpoint of phase II open label single arm study of Chan et al [14] was to assess the change in VEGFR2+ endothelial progenitor cells in women treated with tetrathiomolybdate. The study, performed on 36 women with stage II/III TNBC during adjuvant setting, showed that two year event free survival was $90 \%$.

\section{Zoledronic acid}

The articles of Hasegawa et al [15] and Ishikawa [16] referred to the same phase II, open label, randomised study but analysed different outcomes in the same cohort of patients ( 34 women with stage IIA/IIIB TNBC) treated with zoledronic acid plus chemotherapy versus chemotherapy in neoadjuvant setting. Pathological complete response was not significant $(p=0.112)$ when comparing neoadjuvant chemotherapy plus zoledronic acid $(6 / 17(35.3 \%) \mathrm{Cl}$ : 12.6-58.0) with chemotherapy alone (2/17 (11.8\%) Cl: 0.0-27.1). Also for the 3 years disease free survival, neoadjuvant chemotherapy plus zoledronic acid showed no significant benefit compared to the neoadjuvant treatment alone $(p=0.077)$ despite the fact that the percentage of patients in treatment with zoledronic acid was higher compared to the other arm $(94.1 \%$ versus $70.6 \%)$.

\section{NSAIDs}

Celecoxib was analysed in two studies: the first, a phase II randomised study of Pierga et al [21] performed between 2004 and 2007, analysed 23 women with stage II/III TNBC comparing chemotherapy alone with chemotherapy plus celecoxib. The authors stated that celecoxib did not improve pathological complete response rates, but no specific comparison on this outcome were shown in the article for TNBC patients. The second study, a phase II multicentre open-label single arm study of Chow et al [18], analysed women 
with primary breast cancer. Unfortunately, only two patients with primary TNBC were included and authors could not show any result about this cohort.

Aspirin was analysed in two retrospective studies. The first retrospective study of Shiao et al [19] that collected medical records from University of Texas Southwestern TNBC registry, analysed a cohort of 222 women with stage II/III TNBC in the USA between 2005 abd 2013. Sixty-five women were treated with anti-platelet therapy (as aspirin or clopidogrel) and 157 with no anti-platelet therapy. A percentage of patients in both arms (6.3\% and 7.1\%, respectively) did not receive chemotherapy. Five years disease free survival and 5 years distant metastasis hazard ratios was significantly improved in favour of the first arm (anti-platelet 80.4\%, no anti-platelet 62.3\%, HR: 0.503 (0.261-0.970); $p=0.04$; anti-platelet $8.8 \%$, no anti-platelet $31.9 \%$, HR: $0.310(0.132-0.729) ; p=0.007$, respectively). Five years overall survival hazard ratio was not significant between the two arms (HR: $0.652(0.343-1.239) ; p=0.192)$. The second retrospective study of Williams et al [20] performed in USA used electronic medical records of 147 women with primary operable stages I-III TNBC (114 never used aspirin, 19 before diagnosis, and 14 after diagnosis) to analyse overall survival and disease-free survival between 2005 and 2013. Results of this study indicated that aspirin may have an impact on the pathogenesis of TNBC but do not seem to affect breast cancer survival when used after cancer diagnosis (results were presented only for the total cohort of breast cancer patients and not for TNBC subtype).

Finally, Retsky et al [17] showed the updated results of a retrospective study performed in Belgium using medical records between 2003 and 2008 [27], in which ketorolac plus chemotherapy was compared to chemotherapy alone in women who underwent mastectomy with axillary dissection. No information about the cohort (as for the number of patients with TNBC, age, etc...) was reported. Also, for the results the authors said that the group receiving chemotherapy plus ketorolac showed a 'far superior disease free survival in the first few years after surgery' but no data were shown in particular about TNBC.

\section{Itraconazole}

The article of Tsubamoto et al [22] reported the results of a retrospective study that used medical records of the Kohan hospital in Japan between 2008 and 2012 to analye response rate, median progression-free survival and median overall survival of thirteen patients. TNBC patients who progressed after prior chemotherapy were treated with chemotherapy in combination with itraconazole. No comparison was made. The authors showed that response rate was $62 \%$ ([Cl], 35\%-88\%), progression free survival was 10.8 months $(95 \% \mathrm{Cl}, 7.6-15.3)$ and overall survival was 20.4 months ( $95 \% \mathrm{Cl}$ : $13.1-41.4$ months).

\section{Esomeprazole}

The phase II, open label, randomised study of Wang et al [23] analysed a cohort of 15 women with metastatic or recurrent TNBC (seven receiving only chemotherapy, two esomeprazole low dose and six esomeprazole high dose). The authors showed that the time to progression of patients receiving esomeprazole when compared to chemotherapy was significantly higher (10.7 versus 5.8 months; $p=0.011$ ).

\section{Mifepristone}

In the Phase I, randomised study of Nanda and colleagues performed in USA, four women with metastatic or locally advanced TNBC were analysed (those patients were allocated to mifepristone plus paclitaxel or placebo). Unfortunately, no information about patients allocation, nor any outcome information could be retrieved from this article [24].

\section{Statins}

The retrospective study of Shaitelman et al [26] used medical records from the MD Anderson Cancer Centre to investigate if women with stage I-III TNBC receiving statins at any time from diagnosis. The authors showed that patients receiving statins did not get any advantage compared to the non-statin users group (0.82 (0.57-1.16); 0.70 (0.47-1.03) relative risk of recurrence and breast cancer death, respectively); when a multivariate analysis was performed (taking in consideration cholesterol and triglyceride values, stage and chemotherapy, the authors showed that statin use was predictive for OS (HR: 0.10, $p=0.026,95 \% \mathrm{Cl}: 0.01-0.76$ ). 
The retrospective study of Lacerda et al [25] using Breast Cancer Management database at MD Anderson Cancer Centre in USA between 1995 and 2011, analysed the risk of loco-regional recurrence at 3 years associated to the use of statins, in patients with inflammatory breast cancer who received adjuvant post-mastectomy radiotherapy. 102 patients underwent post-mastectomy radiation (86 patients) or postmastectomy radiation plus statins (16 patients). Unfortunately no information about the outcome in TNBC patients was shown.

\section{Clinicaltrials.gov}

Searching the web site of clinicaltrials.gov (clinicaltrials.gov), we found only 17 drugs out of 286 presented in the ReDo_DB with ongoing or completed clinical trials for TNBC. Table 3 shows the list of trials and the recruitment status for each drug. As shown in Table 3 , most part of the drugs present only one or few studies published on this website. In total, three studies are recruiting for the assessment of atorvastatin, two for metformin, two for mifepristone, and three for zoledronic acid.

\section{Future directions}

This review presents an overview of all the evidences about the repurposing of old, licensed, non-cancer-drugs in the treatment of TNBC, starting from preclinical evidence and going through current clinical trials. ReDO is an ambitious project aiming to investigate the repurposing of non-cancer-drugs in oncology, and ReDO_DB is a powerful tool that need to be dynamically implemented with recent findings, by adding to the database new drugs for which there are preclinical evidence, and by giving visitors a specific PubMed search string for each tumour and tumour subtypes. The ReDO approach is based on published literature and does not aim to identify new active compounds against cancer. Thus, the database does not include potential repurposing candidates identified through in silico modelling or other computational pharmacological approaches that, despite the interest for the research [28-31], unless validated by preclinical studies, represent only future hypothetical repurposed drugs and far from the aim of the ReDO project. The project, in particular, aims to drive scientist attention to investigate already approved non cancer-drugs in the oncology setting. Using this ReDO_DB, we found out that despite a lot of preclinical evidence was produced for drugs included in the database for the treatment of TNBC, only few of them were tested in clinical trials. Moreover, in clinical trials only few of the studies used a large sample of cases and gave explicit results on the repurposing of old drugs for TNBC. Some of the studies did not report any result for TNBC cohort when this is a part of a bigger BC cohort.

Beta Blockers (BBs) seem to be the more promising drugs in the repurposing for the treatment of TNBC. Three articles showed significant benefits of these drugs in women with advanced TNBC and in early primary TNBC patients treated with the combination of chemotherapy plus BBs [11-13]. Unfortunately, in clinicaltrials.gov we found no studies that specifically attempt to evaluate BBs within clinical trials for TNBC patients. One triple blinded phase II randomised trial evaluated the use of pre-operative propranolol (seven days before surgery) compared to placebo in 60 women with early stage surgically-resectable breast cancer. [32]. The authors showed that the treatment with propranolol reduced intra-tumoral mesenchymal transition and promoted immune cell infiltration reducing biomarkers associated with metastatic potential. Unfortunately, authors did not present results stratified for breast cancer sub-type.

While BBs demonstrated to be beneficial in the treatment of TNBC, metformin, a promising molecule in preclinical studies, did not show any efficacy in the treatment of women with TNBC. Bayraktar et al [10] showed that metformin does not improve survival outcomes in a population of TNBC women when compared to not users. Of note, two studies on the use of metformin in clinicaltrials.gov on TNBC patients are ongoing.

The articles of Shiao et al [19] and Williams et al [20] showed conflicting results on aspirin. While the first study showed a significant survival benefit in women with stage II/III by the use of aspirin, Williams et al [20] did not show this benefit in the breast cancer population examined (women with operable stage I-III TNBC).

Despite many studies trying to evaluate the use of statins in breast cancer treatment [33-36], in the literature search on PubMed, we retrieved only two retrospective studies on their use in the TNBC cohort. The article of Shaitelman et al [26] reported a non-significant improvement of OS for patients in the statin group (with the exception of the multivariate analysis), while the second study of Lacerda et al [25] did not show any results for TNBC patients. 
Table 3. Ongoing trials found in Clinicaltrials.gov.

\begin{tabular}{|c|c|c|c|}
\hline Drugs (REDO_DB) & Main indication & Mechanism of action & Clinical trial.gov \\
\hline Acetylsalicylic acid & $\begin{array}{l}\text { Analgesia, swelling, prophylaxis of } \\
\text { venous embolism and further heart } \\
\text { attacks or strokes }\end{array}$ & Cyclooxygenase inhibitor & (3) \\
\hline Atorvastatin & $\begin{array}{l}\text { Coronary heart disease, acute coro- } \\
\text { nary syndrome }\end{array}$ & HMGCR inhibitor & $\begin{array}{l}\text { NCT03358017 (Recruitment Status: } \\
\text { Recruiting); } \\
\text { NCT03872388 (Recruitment Status: } \\
\text { Recruiting); } \\
\text { NCT02201381 (Recruitment Status: } \\
\text { Recruiting) }\end{array}$ \\
\hline Celecoxib & $\begin{array}{l}\text { OA, RA, JRA, AS, acute pain, primary } \\
\text { dysmenorrhea }\end{array}$ & Cyclooxygenase inhibitor & $\begin{array}{l}\text { NCT03599453 (Recruitment Status: } \\
\text { Recruiting) }\end{array}$ \\
\hline Doxycycline & $\begin{array}{l}\text { Respiratory/urinary tract/ophtalmic } \\
\text { infection }\end{array}$ & Metalloproteinase inhibitor & $\begin{array}{l}\text { NCT02201381 (Recruitment Status: } \\
\text { Recruiting) }\end{array}$ \\
\hline Epalrestat & Diabetes & Aldose reductase inhibitor & $\begin{array}{l}\text { NCT03244358 (Recruitment Status: } \\
\text { Recruiting) }\end{array}$ \\
\hline Flucytosine & Candida and/or Cryptococcus & Other antifungal & $\begin{array}{l}\text { NCT02576665 (Recruitment Status: } \\
\text { Active) }\end{array}$ \\
\hline Imipramine & Depression & $\begin{array}{l}\text { Norepinephrine reputake inhibitor|serotonin } \\
\text { reuptake inhibitor }\end{array}$ & $\begin{array}{l}\text { NCT03122444 (Recruitment Status : Not } \\
\text { yet recruiting) }\end{array}$ \\
\hline Indomethacin & Analgesia & Cyclooxygenase inhibitor & $\begin{array}{l}\text { NCT02950259 (Recruitment Status: } \\
\text { Active) }\end{array}$ \\
\hline Lansoprazole & Antacid & ATPase inhibitor & $\begin{array}{l}\text { NCT03794596 (Recruitment Status : Not } \\
\text { yet recruiting) }\end{array}$ \\
\hline Leflunomide & Arthritis & $\begin{array}{l}\text { Dihydroorotate dehydrogenase inhibitor|PDGFR } \\
\text { tyrosine kinase receptor inhibitor }\end{array}$ & $\begin{array}{l}\text { NCT03709446 (Recruitment Status: } \\
\text { Recruiting) }\end{array}$ \\
\hline Mebendazole & Parasitic infection & Tubulin polymerisation inhibitor & $\begin{array}{l}\text { NCT02201381 (Recruitment Status: } \\
\text { Recruiting) }\end{array}$ \\
\hline Metformin & Diabetes & Insulin sensitizer & $\begin{array}{l}\text { NCT01650506 (Recruitment Status : } \\
\text { Completed); NCT02201381 (Recruitment } \\
\text { Status : Recruiting) }\end{array}$ \\
\hline Mifepristone & Abortifacient & $\begin{array}{l}\text { Glucocorticoid receptor ntagonist|progesterone } \\
\text { receptor antagonist }\end{array}$ & $\begin{array}{l}\text { NCT02788981 (Recruitment Status : } \\
\text { Recruiting) } \\
\text { NCT02014337 (Recruitment Status : } \\
\text { Completed) }\end{array}$ \\
\hline Omeprazole & Antacid & ATPase inhibitor & $\begin{array}{l}\text { NCT02950259 (Recruitment Status : } \\
\text { Active) }\end{array}$ \\
\hline Ritonavir & Anti-retroviral & HIV protease inhibitor & $\begin{array}{l}\text { NCT01009437 (Recruitment Status: } \\
\text { Completed) }\end{array}$ \\
\hline Zoledronic acid & $\begin{array}{l}\text { Osteoporosis, prophylaxis of skeletal } \\
\text { fractures and treat hypercalcemia } \\
\text { of malignancy, treat pain from bone } \\
\text { metastases }\end{array}$ & Bone resorption inhibitor & $\begin{array}{l}\text { NCT03358017 (Recruitment Status: } \\
\text { Recruiting); } \\
\text { NCT02595138 (Recruitment Status: } \\
\text { Active) } \\
\text { NCT02347163 (Recruitment Status: } \\
\text { Stopped due to the low accrual rate)) }\end{array}$ \\
\hline
\end{tabular}


Other authors showed significant results on the survival of TNBC patients treated with esomeprazole. Recently, one phase II study on activity of omeprazole on patients with operable TNBC independent of baseline Fatty acid synthase (FASN) expression was presented at the ASCO meeting. [37] In vitro, proton pump inhibitors inhibit FASN activity and induce apoptosis in breast cancer cell lines. In this study, omeprazole in combination with anthracycline-taxane (AC-T) was administered to 42 patients until surgery, and pathologic complete response (pCR) was investigated. FASN positivity significantly decreased with omeprazole from $0.53(\mathrm{SD}=0.25)$ at baseline to 0.38 (SD $=0.30 ; p=0.02$ ), and the drug was well tolerated with no known grade 3 or 4 toxicities. Furthermore, the pCR rate was 71.4\% (95\% Cl: 51.3-86.8) in FASN+ patients and $71.8 \%(95 \% \mathrm{Cl}: 55.1-85.0)$ in all enrolled patients, demonstrating that the omeprazole in addition to neoadjuvant AC-T yields a promising $\mathrm{pCR}$ rate without adding toxicity.

For those drugs collected in ReDO_DB with favourable preclinical evidence or whose retrospective clinical trials were not so large to provide strong evidence, large retrospective cohort studies are needed to evaluate effectiveness. Further, as for BBs that have proven by retrospective studies to be effective in the treatment of TNBC patients, randomised clinical trials might be important to confirm the evidence of the repurposing.

\section{Final remarks}

Drug repurposing is a highly interesting novel strategy for the oncology community and ReDO_DB is a powerful tool that can give authors the opportunity to investigate weather non-anticancer drugs might be effective in cancer treatment. Some precision medicine studies, based on omics data, have included repurposed drugs and have reported interesting case reports of responses from patients [38, 39], however no one on TNBC. Due to the low number of therapeutic opportunities approved for TNBC, repurposing of old drugs seems a valuable approach for this particular type of cancer.

From the literature retrieved, BBs seemed to be the more promising drugs for the repurposing, while evidence about other drugs as NSAIDs still need to be assessed or proven for the treatment of TNBC.

\section{Conflicts of interest}

The authors declare that they have no conflict of interest

\section{Authors' contributions}

MZ and SC conceived the study. AS extracted the data. SD supervised the data extraction. MZ, SD, SC, AS, and PP contributed to the interpretation and discussion of study results. AS and SD drafted the manuscripts. All authors revised and approved the final version of the paper.

\section{Funding}

This study was supported by Fondazione Decima Regio 'Olga e Raimondo Curri', Via Cimarra 44-B, Roma. 


\section{References}

1. Perou CM (2010) Molecular stratification of ripple-negative breast cancers Oncologist 15(S5) 39-48 https://doi.org/10.1634/ theoncologist.2010-S5-39

2. Brouckaert $\mathrm{O}$, Wildiers $\mathrm{H}$, and Floris $\mathrm{G}$, et al (2012) Update on triple-negative breast cancer: prognosis and management strategies Int J Women's Health 4 511-520. PMID: 23071421 PMCID: 3469230

3. Gucalp A and Traina TA (2011) Triple-negative breast cancer: adjuvant therapeutic options Chemother Res Pract 2011696208

4. Dent R, Trudeau M, and Pritchard Kl, et al (2007) Triple-negative breast cancer: clinical features and patterns of recurrence Clin Cancer Res 13(15) 4429-4434 https://doi.org/10.1158/1078-0432.CCR-06-3045 PMID: 17671126

5. Spini A, Roberto G, and Gini R, et al (2019) Evidence of $\beta$-blockers drug repurposing for the treatment of triple negative breast cancer: a systematic review Neoplasma 66(6) 963-970 https://doi.org/10.4149/neo_2019_190110N34 PMID: 31607128

6. Pushpakom S, lorio F, and Eyers PA, et al (2019) Drug repurposing: progress, challenges and recommendations Nat Rev Drug Discov 18(1) 41-58 https://doi.org/10.1038/nrd.2018.168

7. Goldstein DA, Stemmer SM, and Gordon N (2016) The cost and value of cancer drugs-are new innovations outpacing our ability to pay? Isr J Health Policy Res 540 https://doi.org/10.1186/s13584-016-0097-0

8. Pantziarka P, Verbaanderd C, and Sukhatme V, et al (2018) ReDO_DB: the repurposing drugs in oncology database Ecancermedicalscience 12886 https://doi.org/10.3332/ecancer.2018.886

9. ClinicalTrials.gov [https://clinicaltrials.gov/] Date accessed: 31/03/19

10. Bayraktar S, Hernadez-Aya LF, and Lei X, et al. (2012) Effect of metformin on survival outcomes in diabetic patients with triple receptornegative breast cancer Cancer 118(5) 1202-1211 https://doi.org/10.1002/cncr.26439

11. Botteri E, Munzione E, and Rotmensz N, et al (2013) Therapeutic effect of beta-blockers in triple-negative breast cancer postmenopausal women. Breast cancer research and treatment Breast Cancer Res Treat 140(3) 567-575 https://doi.org/10.1007/s10549-0132654-3 PMID: 23912960

12. Melhem-Bertrandt A, Chavez-Macgregor M, and Lei X, et al (2011) Beta-blocker use is associated with improved relapse-free survival in patients with triple-negative breast cancer J Clin Oncol 29(19) 2645-2652 https://doi.org/10.1200/JCO.2010.33.4441 PMID: 21632501 PMCID: 3139371

13. Spera G, Fresco R, and Fung $\mathrm{H}$, et al (2017) Beta blockers and improved progression-free survival in patients with advanced HER2 negative breast cancer: a retrospective analysis of the ROSE/TRIO-012 study Ann Oncol 28(8) 1836-1841 https://doi.org/10.1093/annonc/ mdx264 PMID: 28520849

14. Chan N, Willis A, and Kornhauser N, et al (2017) Influencing the tumor microenvironment: a phase II study of copper depletion using tetrathiomolybdate in patients with breast cancer at high risk for recurrence and in preclinical models of lung metastases Clin Cancer Res 23(3) 666-676 https://doi.org/10.1158/1078-0432.CCR-16-1326

15. Hasegawa $\mathrm{Y}$, Tanino $\mathrm{H}$, and Horiguchi J, et al (2015) Randomized controlled trial of zoledronic acid plus chemotherapy versus chemotherapy alone as neoadjuvant treatment of HER2-negative primary breast cancer (JONIE study) PLoS One 10(12) e0143643 https://doi. org/10.1371/journal.pone.0143643 PMID: 26633806 PMCID: 4669153

16. Ishikawa T, Akazawa K, and Hasegawa Y, et al (2017) Survival outcomes of neoadjuvant chemotherapy with zoledronic acid for HER2negative breast cancer J Surg Res 220 46-51 https://doi.org/10.1016/j.jss.2017.05.066 PMID: 29180210

17. Retsky M, Rogers R, and Demicheli R, et al (2012) NSAID analgesic ketorolac used perioperatively may suppress early breast cancer relapse: particular relevance to triple negative subgroup Breast Cancer Res Treat 134(2) 881-888 https://doi.org/10.1007/s10549-0122094-5 PMID: 22622810 
18. Chow LWC, Tung SY, and Ng T-Y, et al (2013) Concurrent celecoxib with 5-fluorouracil/epirubicin/cyclophosphamide followed by docetaxel for stages II - III invasive breast cancer: the OOTR-N001 study Expert Opin Investig Drugs 22(3) 299-307 https://doi.org/10. 1517/13543784.2013.766715 PMID: 23394482

19. Shiao J, Thomas KM, and Rahimi AS, et al (2017) Aspirin/antiplatelet agent use improves disease-free survival and reduces the risk of distant metastases in Stage II and III triple-negative breast cancer patients Breast Cancer Res Treat 161(3) 463-471 https://doi. org/10.1007/s10549-016-4081-8

20. Williams AD, Li YR, and So A, et al (2018) The impact of aspirin use on breast cancer subtype and clinical course J Surg Res $23071-79$ https://doi.org/10.1016/j.jss.2018.04.040 PMID: 30100043

21. Pierga J-Y, Delaloge S, and Espié M, et al (2010) A multicenter randomized phase II study of sequential epirubicin/cyclophosphamide followed by docetaxel with or without celecoxib or trastuzumab according to HER2 status, as primary chemotherapy for localized invasive breast cancer patients Breast Cancer Res Treat 122(2) 429-437 https://doi.org/10.1007/s10549-010-0939-3 PMID: 20480225

22. Tsubamoto H, Sonoda T, and Inoue K. (2014) Impact of itraconazole on the survival of heavily pre-treated patients with triple-negative breast cancer Anticancer Res 34(7) 3839-3844 PMID: 24982411

23. Wang B-Y, Zhang J, and Wang J-L, et al (2015) Intermittent high dose proton pump inhibitor enhances the antitumor effects of chemotherapy in metastatic breast cancer J Exp Clin Cancer Res 3485 https://doi.org/10.1186/s13046-015-0194-x PMID: 26297142 PMCID: 4546346

24. Nanda R, Stringer-Reasor EM, and Saha P, et al (2016) A randomized phase I trial of nanoparticle albumin-bound paclitaxel with or without mifepristone for advanced breast cancer Springerplus 5(1) 947 https://doi.org/10.1186/s40064-016-2457-1 PMID: 27386391 PMCID: 4929099

25. Lacerda L, Reddy JP, and Liu D, et al (2014) Simvastatin radiosensitizes differentiated and stem-like breast cancer cell lines and is associated with improved local control in inflammatory breast cancer patients treated with postmastectomy radiation Stem Cells Transl Med 3(7) 849-856 https://doi.org/10.5966/sctm.2013-0204 PMID: 24833589 PMCID: 4073823

26. Shaitelman SF, Stauder MC, and Allen P, et al (2017) Impact of statin use on outcomes in triple negative breast cancer J Cancer 8(11) 2026-2032 https://doi.org/10.7150/jca.18743 PMID: 28819403 PMCID: 5559964

27. Forget $P$, Berlière $M$, and van Maanen A, et al (2013) Perioperative ketorolac in high risk breast cancer patients. Rationale, feasibility and methodology of a prospective randomized placebo-controlled trial Med Hypotheses 81(4) 707-712 https://doi.org/10.1016/j. mehy.2013.07.033 PMID: 23937996

28. Vitali F, Cohen LD, and Demartini A, et al (2016) A network-based data integration approach to support drug repurposing and multitarget therapies in triple negative breast cancer PLoS One 11(9) e0162407 https://doi.org/10.1371/journal.pone.0162407 PMID: 27632168 PMCID: 5025072

29. Turanli B, Karagoz K, and Gulfidan G, et al (2018) A network-based cancer drug discovery: from integrated multi-omics approaches to precision medicine Curr Pharm Des 24(32) 3778-3790 https://doi.org/10.2174/1381612824666181106095959 PMID: 30398107

30. Ocana A and Pandiella A (2017) Targeting oncogenic vulnerabilities in triple negative breast cancer: biological bases and ongoing clinical studies Oncotarget 18 8(13):22218-34 https://doi.org/10.18632/oncotarget.14731

31. Bianchini G, Balko JM, and Mayer IA, et al (2016) Triple-negative breast cancer: challenges and opportunities of a heterogeneous disease Nat Rev Clin Oncol 13(11) 674-690 https://doi.org/10.1038/nrclinonc.2016.66 PMID: 27184417 PMCID: 5461122

32. Hiller JG, Cole SW, and Crone EM, et al (2020) Pre-operative $\beta$-blockade with propranolol reduces biomarkers of metastasis in breast cancer: a Phase II randomized trial Clin Cancer Res 26(8) 1803-1811 https://doi.org/10.1158/1078-0432.CCR-19-2641

33. Ahern TP, Pedersen L, and Tarp M, et al (2011) Statin prescriptions and breast cancer recurrence risk: a Danish nationwide prospective cohort study J Natl Cancer Inst 103(19) 1461-1468 https://doi.org/10.1093/jnci/djr291 PMID: 21813413 PMCID: 3186780 
34. Boudreau DM, Yu O, and Chubak J, et al (2014) Comparative safety of cardiovascular medication use and breast cancer outcomes among women with early stage breast cancer Breast Cancer Res Treat 144(2) 405-416 https://doi.org/10.1007/s10549-014-2870-5 PMID: 24557337 PMCID: 3988288

35. Kwan ML, Habel LA, and Flick ED, et al (2008) Post-diagnosis statin use and breast cancer recurrence in a prospective cohort study of early stage breast cancer survivors Breast Cancer Res Treat 109(3) 573-579 https://doi.org/10.1007/s10549-007-9683-8

36. Murtola TJ, Visvanathan $\mathrm{K}$, and Artama M, et al Statin use and breast cancer survival: a nationwide cohort study from Finland PLoS One 9(10) ell0231

37. Sardesai SD, Thomas A, and Gallagher C, et al (2020) Inhibiting fatty acid synthase in operable triple negative breast cancer J Clin Oncol 38(suppl; abstr 584) https://doi.org/10.1200/JCO.2020.38.15_suppl.584

38. Brown RE, Buryanek J, and McGuire MF (2017) Metformin and melatonin in adrenocortical carcinoma: morphoproteomics and biomedical analytics provide proof of concept in a case study Ann Clin Lab Sci 47(4) 457-465 PMID: 28801373

39. Jones MR, Schrader KA, and Shen Y, et al (2016) Response to angiotensin blockade with irbesartan in a patient with metastatic colorectal cancer Ann Oncol 27(5) 801-806 https://doi.org/10.1093/annonc/mdw060 PMID: 27022066 PMCID: 4843189 


\section{Supplementary tables}

Table S1. Search strings.

\begin{tabular}{|l|}
\hline PubMED String: 3 blocks combined with AND \\
\hline Pathology block \\
\hline "Triple negative breast cancer"[Title/Abstract] OR "TNBC"[Title/Abstract] OR "Triple negative breast neoplasms"[Mesh] \\
\hline Intervention Block \\
\hline "Repurposing"[All Fields] OR "Repurpose"[All Fields] OR "Repositioning"[All fields] OR "Reposition"[All Fields] \\
\hline Type of study Block \\
\hline "Clinical trial"[Publication type] OR "Clinical Study"[Publication Type] OR "Epidemiologic Studies"[Mesh] \\
\hline \\
\hline PubMED sting based on ReDO_DB: 2 blocks combined with AND \\
\hline Drugs block: all the drugs and their synonyms in the Redo Database \\
\hline Pathology block \\
\hline "Triple negative breast cancer"[Title/Abstract] OR "TNBC"[Title/Abstract] OR "Triple negative breast neoplasms"[Mesh] \\
\hline
\end{tabular}

Table S2. Preclinical references for repurposing of drugs for TNBC by ReDO DB.

\begin{tabular}{|c|c|c|c|}
\hline Drugs & Main indication & Mechanism of action & References \\
\hline $\begin{array}{l}\text { Acetamino- } \\
\text { phen }\end{array}$ & Analgesia & TRPA1 inhibitor & $\begin{array}{l}\text {-Afshar E, Hashemi-Arabi M, Salami S, Peirouvi T, Pouriran R. Screening of } \\
\text { acetaminophen-induced alterations in epithelial-to-mesenchymal transition- } \\
\text { related expression of microRNAs in a model of stem-like triple-negative breast } \\
\text { cancer cells: The possible functional impacts. Gene. } 2019 \text { Jun 20;702:46-55. }\end{array}$ \\
\hline Acetazolamide & $\begin{array}{l}\text { Glaucoma, di- } \\
\text { uretic, epilepsy }\end{array}$ & Carbonic anhydrase inhibitor & $\begin{array}{l}\text {-Ivanova L, Zandberga E, Silina K, Kalnina Z, Ābols A, Endzelinš E, et al. Prognos- } \\
\text { tic relevance of carbonic anhydrase IX expression is distinct in various subtypes } \\
\text { of breast cancer and its silencing suppresses self-renewal capacity of breast } \\
\text { cancer cells. Cancer Chemother Pharmacol. } 2015 \text { Feb;75(2):235-46 } \\
\text { - Tatiparti K, Sau S, Gawde KA, Iyer AK. Copper-Free "Click" Chemistry-Based } \\
\text { Synthesis and Characterisation of Carbonic Anhydrase-IX Anchored Albumin- } \\
\text { Paclitaxel Nanoparticles for Targeting Tumor Hypoxia. Int J Mol Sci. } 2018 \text { Mar } \\
\text { 13;19(3). }\end{array}$ \\
\hline
\end{tabular}


Table S2. Preclinical references for repurposing of drugs for TNBC by ReDO DB. (continued)

\begin{tabular}{|c|c|c|c|}
\hline $\begin{array}{l}\text { Acetylsalicylic } \\
\text { acid }\end{array}$ & $\begin{array}{l}\text { Analgesia, swell- } \\
\text { ing, prophylaxis of } \\
\text { venous embolism } \\
\text { and further heart } \\
\text { attacks or strokes }\end{array}$ & Cyclooxygenase inhibitor & $\begin{array}{l}\text {-Bhardwaj A, Singh H, Trinidad CM, Albarracin CT, Hunt KK, Bedrosian I. The } \\
\text { isomiR-140-3p-regulated mevalonic acid pathway as a potential target for pre- } \\
\text { vention of triple negative breast cancer. Breast Cancer Res. } 2018 \text { 11;20(1):150. } \\
\text {-Amaral MEA, Nery LR, Leite CE, de Azevedo Junior WF, Campos MM. Pre- } \\
\text { clinical effects of metformin and aspirin on the cell lines of different breast } \\
\text { cancer subtypes. Invest New Drugs. 2018;36(5):782-96. } \\
\text {-Talarico G, Orecchioni S, Dallaglio K, Reggiani F, Mancuso P, Calleri A, et al. As- } \\
\text { pirin and atenolol enhance metformin activity against breast cancer by target- } \\
\text { ing both neoplastic and microenvironment cells. Sci Rep. } 2016 \text { Jan 5;6:18673. } \\
\text {-Maity G, Chakraborty J, Ghosh A, Haque I, Banerjee S, Banerjee SK. Aspirin } \\
\text { suppresses tumor cell-induced angiogenesis and their incongruity. J Cell Com- } \\
\text { mun Signal. 2019 Jan } 4 \\
\text {-Hsieh C-C, Wang C-H. Aspirin Disrupts the Crosstalk of Angiogenic and Inflam- } \\
\text { matory Cytokines between 4T1 Breast Cancer Cells and Macrophages. Media- } \\
\text { tors Inflamm. 2018;2018:6380643 } \\
\text {-Basudhar D, Glynn SA, Greer M, Somasundaram V, No JH, Scheiblin DA, et } \\
\text { al. Coexpression of NOS2 and COX2 accelerates tumor growth and reduces } \\
\text { survival in estrogen receptor-negative breast cancer. Proc Natl Acad Sci USA. } \\
\text { 2017 05;114(49):13030-5 } \\
\text {-Lee YR, Kim KM, Jeon BH, Choi S. Extracellularly secreted APE1/Ref-1 triggers } \\
\text { apoptosis in triple-negative breast cancer cells via RAGE binding, which is me- } \\
\text { diated through acetylation. Oncotarget. 2015 Sep 15;6(27):23383-98 } \\
\text {-Chattopadhyay M, Kodela R, Nath N, Barsegian A, Boring D, Kashfi K. Hydro- } \\
\text { gen sulfide-releasing aspirin suppresses NF-KB signaling in estrogen receptor } \\
\text { negative breast cancer cells in vitro and in vivo. Biochem Pharmacol. 2012 Mar } \\
\text { 15;83(6):723-32 }\end{array}$ \\
\hline Albendazole & Parasitic infection & Tubulin polymerisation inhibitor & $\begin{array}{l}\text {-Priotti J, Baglioni MV, García A, Rico MJ, Leonardi D, Lamas MC, et al. } \\
\text { Repositioning of Anti-parasitic Drugs in Cyclodextrin Inclusion Complexes } \\
\text { for Treatment of Triple-Negative Breast Cancer. AAPS PharmSciTech. } 2018 \\
\text { Nov;19(8):3734-41. }\end{array}$ \\
\hline Amiloride & $\begin{array}{l}\text { In congestive } \\
\text { heart failure or } \\
\text { hypertension } \\
\text { treated with thia- } \\
\text { zides, to conserve } \\
\text { potassium }\end{array}$ & Sodium channel blocker & $\begin{array}{l}\text {-Amith SR, Wilkinson JM, Baksh S, Fliegel L. The } \mathrm{Na}^{+} / \mathrm{H}^{+} \text {exchanger (NHE1) as a } \\
\text { novel co-adjuvant target in paclitaxel therapy of triple-negative breast cancer } \\
\text { cells. Oncotarget. } 2015 \text { Jan 20;6(2):1262-75. }\end{array}$ \\
\hline Aprepitant & Nausea, vomiting & Tachykinin antagonist & $\begin{array}{l}\text {-Robinson P, Kasembeli M, Bharadwaj U, Engineer N, Eckols KT, Tweardy DJ. } \\
\text { Substance P Receptor Signaling Mediates Doxorubicin-Induced Cardiomyocyte } \\
\text { Apoptosis and Triple-Negative Breast Cancer Chemoresistance. Biomed Res Int. } \\
\text { 2016;2016:1959270 }\end{array}$ \\
\hline Artesunate & Malaria & DNA synthesis inhibitor & $\begin{array}{l}\text {-Greenshields AL, Fernando W, Hoskin DW. The anti-malarial drug artesunate } \\
\text { causes cell cycle arrest and apoptosis of triple-negative MDA-MB-468 and } \\
\text { HER2-enriched SK-BR-3 breast cancer cells. Exp Mol Pathol. 2019;107:10-22. }\end{array}$ \\
\hline
\end{tabular}


Table S2. Preclinical references for repurposing of drugs for TNBC by ReDO DB. (continued)

\begin{tabular}{|c|c|c|c|}
\hline Ascorbic acid & Scurvy & Antioxidant & $\begin{array}{l}\text {-Wu C-W, Liu H-C, Yu Y-L, Hung Y-T, Wei C-W, Yiang G-T. Combined treatment } \\
\text { with vitamin C and methotrexate inhibits triple-negative breast cancer cell } \\
\text { growth by increasing H2O2 accumulation and activating caspase-3 and p38 } \\
\text { pathways. Oncol Rep. } 2017 \text { Apr;37(4):2177-84. } \\
\text {-Hatem E, Azzi S, El Banna N, He T, Heneman-Masurel A, Vernis L, et al. Aura- } \\
\text { nofin/Vitamin C: A Novel Drug Combination Targeting Triple-Negative Breast } \\
\text { Cancer. J Natl Cancer Inst. } 2018 \text { Nov } 20 .\end{array}$ \\
\hline Atenolol & $\begin{array}{l}\text { Hypertension, } \\
\text { angina pectoris }\end{array}$ & Adrenergic receptor antagonist & $\begin{array}{l}\text {-Talarico G, Orecchioni S, Dallaglio K, Reggiani F, Mancuso P, Calleri A, et al. As- } \\
\text { pirin and atenolol enhance metformin activity against breast cancer by target- } \\
\text { ing both neoplastic and microenvironment cells. Sci Rep. } 2016 \text { Jan 5;6:18673 }\end{array}$ \\
\hline Atorvastatin & $\begin{array}{l}\text { Coronary heart } \\
\text { disease, acute } \\
\text { coronary syn- } \\
\text { drome }\end{array}$ & HMGCR inhibitor & $\begin{array}{l}\text { - Rachner TD, Göbel A, Thiele S, Rauner M, Benad-Mehner P, Hadji P, et al. Dick- } \\
\text { kopf-1 is regulated by the mevalonate pathway in breast cancer. Breast Cancer } \\
\text { Res. } 2014 \text { Feb 14;16(1):R20 } \\
\text {-Mafuvadze B, Liang Y, Hyder SM. Cholesterol synthesis inhibitor RO 48-8071 } \\
\text { suppresses transcriptional activity of human estrogen and androgen receptor. } \\
\text { Oncol Rep. } 2014 \text { Oct;32(4):1727-33 } \\
\text { - Koohestanimobarhan S, Salami S, Imeni V, Mohammadi Z, Bayat O. Lipophilic } \\
\text { statins antagonistically alter the major epithelial-to-mesenchymal transition sig- } \\
\text { naling pathways in breast cancer stem-like cells via inhibition of the mevalonate } \\
\text { pathway. J Cell Biochem. } 2018 \text { Sep } 6 .\end{array}$ \\
\hline Auranofin & RA & NFkB pathway inhibitor & $\begin{array}{l}\text {-Raninga PV, Lee AC, Sinha D, Shih Y-Y, Mittal D, Makhale A, et al. Therapeutic } \\
\text { cooperation between auranofin, a thioredoxin reductase inhibitor and anti-PD- } \\
\text { L1 antibody for treatment of triple-negative breast cancer. Int J Cancer. } 2019 \\
\text { May } 15 \\
\text {-Hatem E, Azzi S, El Banna N, He T, Heneman-Masurel A, Vernis L, et al. Aura- } \\
\text { nofin/Vitamin C: A Novel Drug Combination Targeting Triple-Negative Breast } \\
\text { Cancer. J Natl Cancer Inst. } 2018 \text { Nov } 20\end{array}$ \\
\hline Azithromycin & $\begin{array}{l}\text { Bacterial infec- } \\
\text { tion, CAP, PID }\end{array}$ & $\begin{array}{l}\text { Bacterial } 50 \text { S ribosomal subunit } \\
\text { inhibitor }\end{array}$ & \\
\hline Bazedoxifene & Osteoporosis & $\begin{array}{l}\text { selective estrogen receptor } \\
\text { modulator (SERM) }\end{array}$ & $\begin{array}{l}\text {-Fu S, Lin J. Blocking Interleukin-6 and Interleukin-8 Signaling Inhibits Cell } \\
\text { Viability, Colony-forming Activity, and Cell Migration in Human Triple- } \\
\text { negative Breast Cancer and Pancreatic Cancer Cells. Anticancer Res. } 2018 \\
\text { Nov;38(11):6271-9 } \\
\text {-Fu S, Chen X, Lo H-W, Lin J. Combined bazedoxifene and paclitaxel treatments } \\
\text { inhibit cell viability, cell migration, colony formation, and tumor growth and } \\
\text { induce apoptosis in breast cancer. Cancer Lett. } 2019 \text { Apr 28;448:11-9. } \\
\text {-Tian J, Chen X, Fu S, Zhang R, Pan L, Cao Y, et al. Bazedoxifene is a novel IL-6/ } \\
\text { GP130 inhibitor for treating triple-negative breast cancer. Breast Cancer Res } \\
\text { Treat. } 2019 \text { Jun;175(3):553-66 }\end{array}$ \\
\hline Bepridil & $\begin{array}{l}\text { Hypertension and } \\
\text { chronic stable } \\
\text { angina }\end{array}$ & Calcium channel blocker & $\begin{array}{l}\text {-Park S-H, Chung YM, Ma J, Yang Q, Berek JS, Hu MC-T. Pharmacological activa- } \\
\text { tion of FOXO3 suppresses triple-negative breast cancer in vitro and in vivo. } \\
\text { Oncotarget. } 2016 \text { Jul 5;7(27):42110-25. }\end{array}$ \\
\hline
\end{tabular}


Table S2. Preclinical references for repurposing of drugs for TNBC by ReDO DB. (continued)

\begin{tabular}{|c|c|c|c|}
\hline Calcitriol & $\begin{array}{l}\text { Vitamin D defi- } \\
\text { ciency }\end{array}$ & Vitamin D receptor agonist & $\begin{array}{l}\text {-Martínez-Reza I, Díaz L, Barrera D, Segovia-Mendoza M, Pedraza-Sánchez } \\
\text { S, Soca-Chafre G, et al. Calcitriol Inhibits the Proliferation of Triple-Negative } \\
\text { Breast Cancer Cells through a Mechanism Involving the Proinflammatory Cyto- } \\
\text { kines IL-1ß and TNF-a. J Immunol Res. 2019;2019:6384278 } \\
\text {-Zheng W, Cao L, Ouyang L, Zhang Q, Duan B, Zhou W, et al. Anticancer activity } \\
\text { of 1,25-(OH)2D3 against human breast cancer cell lines by targeting Ras/MEK/ } \\
\text { ERK pathway. Onco Targets Ther. 2019;12:721-32 } \\
\text {-Bijian K, Kaldre D, Wang T-T, Su J, Bouttier M, Boucher A, et al. Efficacy of } \\
\text { hybrid vitamin D receptor agonist/histone deacetylase inhibitors in vitamin } \\
\text { D-resistant triple-negative 4T1 breast cancer. J Steroid Biochem Mol Biol. } \\
\text { 2018;177:135-9 } \\
\text {-Bohl L, Guizzardi S, Rodríguez V, Hinrichsen L, Rozados V, Cremonezzi D, et al. } \\
\text { Combined calcitriol and menadione reduces experimental murine triple nega- } \\
\text { tive breast tumor. Biomed Pharmacother. 2017 Oct;94:21-6 } \\
\text {-Shan NL, Wahler J, Lee HJ, Bak MJ, Gupta SD, Maehr H, et al. Vitamin D } \\
\text { compounds inhibit cancer stem-like cells and induce differentiation in triple } \\
\text { negative breast cancer. J Steroid Biochem Mol Biol. 2017;173:122-9 } \\
\text {-Thakkar A, Wang B, Picon-Ruiz M, Buchwald P, Ince TA. Vitamin D and andro- } \\
\text { gen receptor-targeted therapy for triple-negative breast cancer. Breast Cancer } \\
\text { Res Treat. 2016;157(1):77-90 } \\
\text {-Richards SE, Weierstahl KA, Kelts JL. Vitamin D effect on growth and vitamin } \\
\text { D metabolizing enzymes in triple-negative breast cancer. Anticancer Res. 2015 } \\
\text { Feb;35(2):805-10 } \\
\text {-Lopes N, Carvalho J, Durães C, Sousa B, Gomes M, Costa JL, et al. 1Alpha,25- } \\
\text { dihydroxyvitamin D3 induces de novo E-cadherin expression in triple-negative } \\
\text { breast cancer cells by CDH1-promoter demethylation. Anticancer Res. 2012 } \\
\text { Jan;32(1):249-57 }\end{array}$ \\
\hline Carglumic acid & $\begin{array}{l}\text { Hyperammonae- } \\
\text { mia in } \mathrm{N} \text {-acetyl- } \\
\text { glutamate syn- } \\
\text { thase deficiency }\end{array}$ & $\begin{array}{l}\text { Carbamoyl phosphate synthase } \\
\text { activator }\end{array}$ & $\begin{array}{l}\text {-Chen C-T, Chen Y-C, Yamaguchi H, Hung M-C. Carglumic acid promotes apop- } \\
\text { tosis and suppresses cancer cell proliferation in vitro and in vivo. Am J Cancer } \\
\text { Res. } 2015 ; 5(12): 3560-9\end{array}$ \\
\hline Celecoxib & $\begin{array}{l}\text { OA, RA, JRA, } \\
\text { AS, acute pain, } \\
\text { primary dysmen- } \\
\text { orrhea }\end{array}$ & Cyclooxygenase inhibitor & $\begin{array}{l}\text {-Ma Q, Gao Y, Wei D-F, Jiang N-H, Ding L, He X, et al. The effects of celecoxib } \\
\text { on the proliferation and ultrastructural changes of MDA-MB-231 breast cancer } \\
\text { cells. Ultrastruct Pathol. } 2018 \text { Jun;42(3):289-94 } \\
\text {-Thomas S, Sharma N, Golden EB, Cho H, Agarwal P, Gaffney KJ, et al. Pref- } \\
\text { erential killing of triple-negative breast cancer cells in vitro and in vivo when } \\
\text { pharmacological aggravators of endoplasmic reticulum stress are combined } \\
\text { with autophagy inhibitors. Cancer Lett. } 2012 \text { Dec 1;325(1):63-71 }\end{array}$ \\
\hline
\end{tabular}


Table S2. Preclinical references for repurposing of drugs for TNBC by ReDO DB. (continued)

\begin{tabular}{|c|c|c|c|}
\hline Chloroquine & $\begin{array}{l}\text { Malaria, Extraint- } \\
\text { estinal Amebiasis }\end{array}$ & Antimalarial agent & 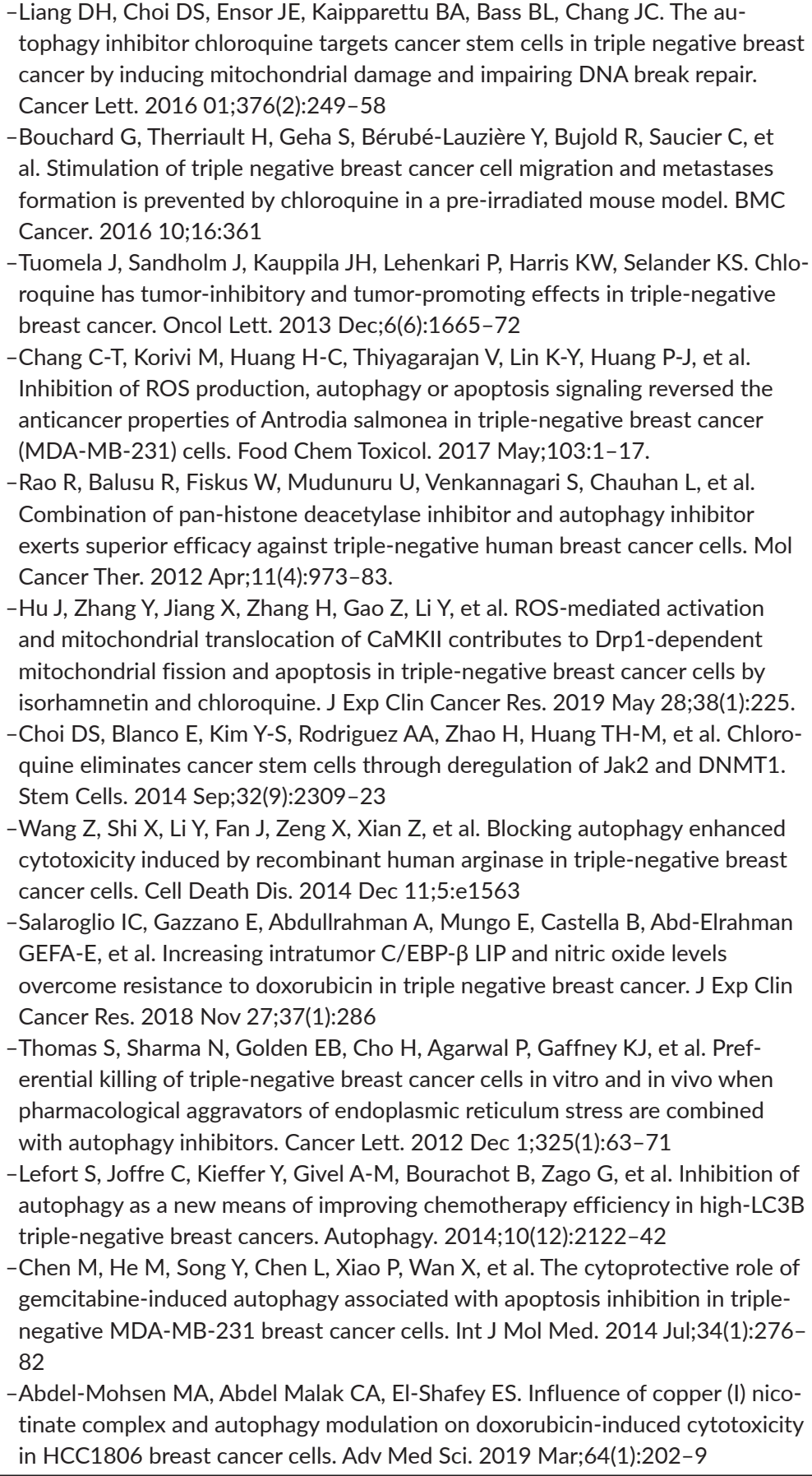 \\
\hline
\end{tabular}


Table S2. Preclinical references for repurposing of drugs for TNBC by ReDO DB. (continued)

\begin{tabular}{|c|c|c|c|}
\hline $\begin{array}{l}\text { Chlorproma- } \\
\text { zine }\end{array}$ & $\begin{array}{l}\text { Psychotic disor- } \\
\text { ders, nausea and } \\
\text { vomiting, anxiety, } \\
\text { hiccups }\end{array}$ & Dopamine receptor antagonist & $\begin{array}{l}\text {-Zhao Y-Q, Yin Y-Q, Liu J, Wang G-H, Huang J, Zhu L-J, et al. Characterization } \\
\text { of HJ-PI01 as a novel Pim-2 inhibitor that induces apoptosis and autophagic } \\
\text { cell death in triple-negative human breast cancer. Acta Pharmacol Sin. } 2016 \\
\text { Sep;37(9):1237-5 }\end{array}$ \\
\hline Cholecalciferol & $\begin{array}{l}\text { Vitamin D defi- } \\
\text { ciency }\end{array}$ & & $\begin{array}{l}\text {-Kutlehria S, Behl G, Patel K, Doddapaneni R, Vhora I, Chowdhury N, et al. Cho- } \\
\text { lecalciferol-PEG Conjugate Based Nanomicelles of Doxorubicin for Treatment } \\
\text { of Triple-Negative Breast Cancer. AAPS PharmSciTech. } 2018 \text { Feb;19(2):792-- } \\
802 .\end{array}$ \\
\hline Ciprofloxacin & Antibiotic & Bacterial DNA gyrase inhibitor & $\begin{array}{l}\text {-Beberok A, Wrześniok D, Rok J, Rzepka Z, Respondek M, Buszman E. Cipro- } \\
\text { floxacin triggers the apoptosis of human triple-negative breast cancer MDA- } \\
\text { MB-231 cells via the p53/Bax/Bcl-2 signaling pathway. Int J Oncol. } 2018 \text { Mar } \\
8\end{array}$ \\
\hline Clotrimazole & Fungal infections & $\begin{array}{l}\text { Cytochrome P450 } \\
\text { inhibitor|imidazoline receptor } \\
\text { ligand }\end{array}$ & $\begin{array}{l}\text {-Zhang P, Yang X, Yin Q, Yi J, Shen W, Zhao L, et al. Inhibition of SK4 Potas- } \\
\text { sium Channels Suppresses Cell Proliferation, Migration and the Epithelial- } \\
\text { Mesenchymal Transition in Triple-Negative Breast Cancer Cells. PLoS ONE. } \\
\text { 2016;11(4):e0154471. }\end{array}$ \\
\hline Colchicine & Gout & Microtubule inhibitor & $\begin{array}{l}\text {-Lindamulage IK, Vu H-Y, Karthikeyan C, Knockleby J, Lee Y-F, Trivedi P, et al. } \\
\text { Novel quinolone chalcones targeting colchicine-binding pocket kill multidrug- } \\
\text { resistant cancer cells by inhibiting tubulin activity and MRP1 function. Sci Rep. } \\
201731 ; 7(1): 10298 .\end{array}$ \\
\hline Danazol & $\begin{array}{l}\text { Endometriosis, } \\
\text { fibrocystic breast } \\
\text { disease, heredi- } \\
\text { tary angioedema }\end{array}$ & $\begin{array}{l}\text { Estrogen receptor } \\
\text { antagonist|progesterone recep- } \\
\text { tor agonist }\end{array}$ & $\begin{array}{l}\text {-Deka SJ, Roy A, Ramakrishnan V, Manna D, Trivedi V. Danazol has potential } \\
\text { to cause PKC translocation, cell cycle dysregulation, and apoptosis in breast } \\
\text { cancer cells. Chem Biol Drug Des. 2017;89(6):953-63 }\end{array}$ \\
\hline Deferasirox & $\begin{array}{l}\text { Acute iron in- } \\
\text { toxication, chronic } \\
\text { iron overload }\end{array}$ & Chelating agent & $\begin{array}{l}\text {-Tury S, Assayag F, Bonin F, Chateau-Joubert S, Servely J-L, Vacher S, et al. The } \\
\text { iron chelator deferasirox synergises with chemotherapy to treat triple-negative } \\
\text { breast cancers. J Pathol. } 2018 \text { Sep;246(1):103-14 }\end{array}$ \\
\hline Deferiprone & $\begin{array}{l}\text { Iron overload in } \\
\text { thalassemia major }\end{array}$ & Chelating agent & $\begin{array}{l}\text {-Knickle A, Fernando W, Greenshields AL, Rupasinghe HPV, Hoskin DW. } \\
\text { Myricetin-induced apoptosis of triple-negative breast cancer cells is mediated } \\
\text { by the iron-dependent generation of reactive oxygen species from hydrogen } \\
\text { peroxide. Food Chem Toxicol. } 2018 \text { Aug;118:154-67 }\end{array}$ \\
\hline Digitoxin & $\begin{array}{l}\text { Congestive HF, } \\
\text { atrial fibrillation, } \\
\text { atrial flutter, PAT, } \\
\text { cardiogenic shock }\end{array}$ & ATPase inhibitor & $\begin{array}{l}\text {-Kulkarni YM, Yakisich JS, Azad N, Venkatadri R, Kaushik V, O'Doherty G, et } \\
\text { al. Anti-tumorigenic effects of a novel digitoxin derivative on both estrogen } \\
\text { receptor-positive and triple-negative breast cancer cells. Tumour Biol. } 2017 \\
\text { Jun;39(6):1010428317705331 }\end{array}$ \\
\hline Digoxin & $\begin{array}{l}\text { Heart failure, } \\
\text { atrial fibrillation }\end{array}$ & ATPase inhibitor & $\begin{array}{l}\text {-Samanta D, Gilkes DM, Chaturvedi P, Xiang L, Semenza GL. Hypoxia-inducible } \\
\text { factors are required for chemotherapy resistance of breast cancer stem cells. } \\
\text { Proc Natl Acad Sci USA. } 2014 \text { Dec 16;111(50):E5429-5438 }\end{array}$ \\
\hline Dipyridamole & $\begin{array}{l}\text { Thromboem- } \\
\text { bolism Prophy- } \\
\text { laxis Post-Cardiac } \\
\text { Valve Replace- } \\
\text { ment }\end{array}$ & Phosphodiesterase inhibitor & $\begin{array}{l}\text {-Spano D, Marshall J-C, Marino N, De Martino D, Romano A, Scoppettuolo MN, } \\
\text { et al. Dipyridamole prevents triple-negative breast-cancer progression. Clin Exp } \\
\text { Metastasis. } 2013 \text { Jan;30(1):47-68 }\end{array}$ \\
\hline
\end{tabular}


Table S2. Preclinical references for repurposing of drugs for TNBC by ReDO DB. (continued)

\begin{tabular}{|c|c|c|c|}
\hline Disulfiram & $\begin{array}{l}\text { Chronic alcohol- } \\
\text { ism }\end{array}$ & $\begin{array}{l}\text { Aldehyde dehydrogenase } \\
\text { inhibitor|DNA methyltransferase } \\
\text { inhibitor|TRPV agonist }\end{array}$ & $\begin{array}{l}\text {-Kim JY, Lee N, Kim Y-J, Cho Y, An H, Oh E, et al. Disulfiram induces anoikis and } \\
\text { suppresses lung colonization in triple-negative breast cancer via calpain activa- } \\
\text { tion. Cancer Lett. } 2017 \text { 01;386:151-60. } \\
\text {-Kim Y-J, Kim JY, Lee N, Oh E, Sung D, Cho T-M, et al. Disulfiram suppresses } \\
\text { cancer stem-like properties and STAT3 signaling in triple-negative breast cancer } \\
\text { cells. Biochem Biophys Res Commun. } 2017 \text { May 13;486(4):1069-76. } \\
\text {-Robinson TJW, Pai M, Liu JC, Vizeacoumar F, Sun T, Egan SE, et al. High- } \\
\text { throughput screen identifies disulfiram as a potential therapeutic for triple- } \\
\text { negative breast cancer cells: interaction with IQ motif-containing factors. Cell } \\
\text { Cycle. } 2013 \text { Sep 15;12(18):3013-24. } \\
\text {-Liu P, Kumar IS, Brown S, Kannappan V, Tawari PE, Tang JZ, et al. Disulfiram } \\
\text { targets cancer stem-like cells and reverses resistance and cross-resistance in } \\
\text { acquired paclitaxel-resistant triple-negative breast cancer cells. Br J Cancer. } \\
\text { 2013 Oct 1;109(7):1876-85. } \\
\text {-Wu L, Meng F, Dong L, Block CJ, Mitchell AV, Wu J, et al. Disulfiram and } \\
\text { BKM120 in Combination with Chemotherapy Impede Tumor Progression and } \\
\text { Delay Tumor Recurrence in Tumor Initiating Cell-Rich TNBC. Sci Rep. } 2019 \text { Jan } \\
\text { 18;9(1):236. }\end{array}$ \\
\hline Doxycycline & $\begin{array}{l}\text { Respiratory/ } \\
\text { urinary tract/oph- } \\
\text { talmic infection }\end{array}$ & Metalloproteinase inhibitor & $\begin{array}{l}\text {-Lin C-C, Lo M-C, Moody RR, Stevers NO, Tinsley SL, Sun D. Doxycycline targets } \\
\text { aldehyde dehydrogenase-positive breast cancer stem cells. Oncol Rep. } 2018 \\
\text { Jun;39(6):3041-7. }\end{array}$ \\
\hline Dutasteride & $\begin{array}{l}\text { Benign prostatic } \\
\text { hyperplasia }\end{array}$ & 5 alpha reductase inhibitor & $\begin{array}{l}\text {-von Wahlde M-K, Hülsewig C, Ruckert C, Götte M, Kiesel L, Bernemann C. The } \\
\text { anti-androgen drug dutasteride renders triple negative breast cancer cells more } \\
\text { sensitive to chemotherapy via inhibition of HIF-1a-/VEGF-signaling. Gynecol } \\
\text { Endocrinol. } 2015 \text { Feb;31(2):160-4. }\end{array}$ \\
\hline Esomeprazole & Antacid & ATPase inhibitor & $\begin{array}{l}\text {-Goh W, Sleptsova-Freidrich I, Petrovic N. Use of proton pump inhibitors as } \\
\text { adjunct treatment for triple-negative breast cancers. An introductory study. J } \\
\text { Pharm Pharm Sci. 2014;17(3):439-46 }\end{array}$ \\
\hline Fasudil & Vasodilator & Rho associated kinase inhibitor & $\begin{array}{l}\text {-Guerra FS, Oliveira RG de, Fraga CAM, Mermelstein CDS, Fernandes PD. ROCK } \\
\text { inhibition with Fasudil induces beta-catenin nuclear translocation and inhibits } \\
\text { cell migration of MDA-MB } 231 \text { human breast cancer cells. Sci Rep. } 2017 \\
\text { 20;7(1):13723. }\end{array}$ \\
\hline Fenofibrate & Hyperlipidemia & PPAR receptor agonist & $\begin{array}{l}\text {-Li T, Zhang Q, Zhang J, Yang G, Shao Z, Luo J, et al. Fenofibrate induces apopto- } \\
\text { sis of triple-negative breast cancer cells via activation of NF-KB pathway. BMC } \\
\text { Cancer. } 2014 \text { Feb 16;14:96. }\end{array}$ \\
\hline Fingolimod & Multiple Sclerosis & $\begin{array}{l}\text { Immunosuppressant|sphingosine } \\
\text { phosphate receptor agonist }\end{array}$ & $\begin{array}{l}\text {-Martin JL, Julovi SM, Lin MZ, de Silva HC, Boyle FM, Baxter RC. Inhibition } \\
\text { of basal-like breast cancer growth by FTY720 in combination with epider- } \\
\text { mal growth factor receptor kinase blockade. Breast Cancer Res. } 2017 \text { Aug } \\
\text { 4;19(1):90. } \\
\text {-Alshaker H, Wang Q, Srivats S, Chao Y, Cooper C, Pchejetski D. New FTY720- } \\
\text { docetaxel nanoparticle therapy overcomes FTY720-induced lymphopenia } \\
\text { and inhibits metastatic breast tumour growth. Breast Cancer Res Treat. } 2017 \\
\text { Oct;165(3):531-43 } \\
\text {-Hait NC, Avni D, Yamada A, Nagahashi M, Aoyagi T, Aoki H, et al. The phos- } \\
\text { phorylated prodrug FTY720 is a histone deacetylase inhibitor that reactivates } \\
\text { ERa expression and enhances hormonal therapy for breast cancer. Oncogen- } \\
\text { esis. } 2015 \text { Jun 8;4:e156 }\end{array}$ \\
\hline
\end{tabular}


Table S2. Preclinical references for repurposing of drugs for TNBC by ReDO DB. (continued)

\begin{tabular}{|c|c|c|c|}
\hline Flubendazole & Parasitic infection & Tubulin polymerisation inhibitor & $\begin{array}{l}\text {-Oh E, Kim Y-J, An H, Sung D, Cho T-M, Farrand L, et al. Flubendazole elicits } \\
\text { anti-metastatic effects in triple-negative breast cancer via STAT3 inhibition. Int } \\
\text { J Cancer. } 2018 \text { 15;143(8):1978-93 } \\
\text {-Zhang L, Guo M, Li J, Zheng Y, Zhang S, Xie T, et al. Systems biology-based } \\
\text { discovery of a potential Atg4B agonist (Flubendazole) that induces autophagy } \\
\text { in breast cancer. Mol Biosyst. } 2015 \text { Nov;11(11):2860-6. }\end{array}$ \\
\hline Fluoxetine & Depression & $\begin{array}{l}\text { Selective serotonin reuptake } \\
\text { inhibitor (SSRI) }\end{array}$ & $\begin{array}{l}\text {-Sun D, Zhu L, Zhao Y, Jiang Y, Chen L, Yu Y, et al. Fluoxetine induces autophagic } \\
\text { cell death via eEF2K-AMPK-mTOR-ULK complex axis in triple negative breast } \\
\text { cancer. Cell Prolif. } 2018 \text { Apr;51(2):e12402. } \\
\text { - Bowie M, Pilie P, Wulfkuhle J, Lem S, Hoffman A, Desai S, et al. Fluoxetine in- } \\
\text { duces cytotoxic endoplasmic reticulum stress and autophagy in triple negative } \\
\text { breast cancer. World J Clin Oncol. } 2015 \text { Dec 10;6(6):299-311 }\end{array}$ \\
\hline Fluvastatin & Hyperlipidemia & HMGCR inhibitor & $\begin{array}{l}\text {-Bhardwaj A, Singh H, Trinidad CM, Albarracin CT, Hunt KK, Bedrosian I. The } \\
\text { isomiR-140-3p-regulated mevalonic acid pathway as a potential target for pre- } \\
\text { vention of triple negative breast cancer. Breast Cancer Res. } 2018 \text { 11;20(1):150. }\end{array}$ \\
\hline Ganciclovir & Anti-viral & DNA polymerase inhibitor & $\begin{array}{l}\text {-Castillo-Rodríguez RA, Arango-Rodríguez ML, Escobedo L, Hernandez-Baltazar } \\
\text { D, Gompel A, Forgez P, et al. Suicide HSVtk gene delivery by neurotensin-poly- } \\
\text { plex nanoparticles via the bloodstream and GCV Treatment specifically inhibit } \\
\text { the growth of human MDA-MB-231 triple negative breast cancer tumors } \\
\text { xenografted in athymic mice. PLoS ONE. 2014;9(5):e97151 } \\
\text {-Devulapally R, Lee T, Barghava-Shah A, Sekar TV, Foygel K, Bachawal SV, et al. } \\
\text { Ultrasound-guided delivery of thymidine kinase-nitroreductase dual therapeu- } \\
\text { tic genes by PEGylated-PLGA/PIE nanoparticles for enhanced triple negative } \\
\text { breast cancer therapy. Nanomedicine (Lond). 2018;13(9):1051-66 }\end{array}$ \\
\hline Hydralazine & Hypertension & Vasodilator & $\begin{array}{l}\text {-Jiang Y, Huang Y, Cheng C, Lu W, Zhang Y, Liu X, et al. Combination of thia- } \\
\text { zolidinedione and hydralazine suppresses proliferation and induces apopto- } \\
\text { sis by PPARY up-expression in MDA-MB-231 cells. Exp Mol Pathol. } 2011 \\
\text { Dec;91(3):768-74 }\end{array}$ \\
\hline $\begin{array}{l}\text { Hydroxychlo- } \\
\text { roquine }\end{array}$ & Malaria & & $\begin{array}{l}\text {-Chittaranjan S, Bortnik S, Dragowska WH, Xu J, Abeysundara N, Leung A, et al. } \\
\text { Autophagy inhibition augments the anticancer effects of epirubicin treatment } \\
\text { in anthracycline-sensitive and -resistant triple-negative breast cancer. Clin } \\
\text { Cancer Res. } 2014 \text { Jun 15;20(12):3159-73 }\end{array}$ \\
\hline Indomethacin & Analgesia & Cyclooxygenase inhibitor & $\begin{array}{l}\text {-Basudhar D, Glynn SA, Greer M, Somasundaram V, No JH, Scheiblin DA, et } \\
\text { al. Coexpression of NOS2 and COX2 accelerates tumor growth and reduces } \\
\text { survival in estrogen receptor-negative breast cancer. Proc Natl Acad Sci USA. } \\
2017 \text { 05;114(49):13030-5. }\end{array}$ \\
\hline Ivermectin & Parasitic infection & Benzodiazepine receptor agonist & $\begin{array}{l}\text {-Kwon Y-J, Petrie K, Leibovitch BA, Zeng L, Mezei M, Howell L, et al. Selective } \\
\text { Inhibition of SIN3 Corepressor with Avermectins as a Novel Therapeutic Strate- } \\
\text { gy in Triple-Negative Breast Cancer. Mol Cancer Ther. } 2015 \text { Aug;14(8):1824-36 }\end{array}$ \\
\hline Leflunomide & Arthritis & $\begin{array}{l}\text { D } \\
\text { Dihydroorotate dehydrogenase } \\
\text { inhibitor|PDGFR tyrosine kinase } \\
\text { receptor inhibitor }\end{array}$ & $\begin{array}{l}\text {-Brown KK, Spinelli JB, Asara JM, Toker A. Adaptive Reprogramming of De Novo } \\
\text { Pyrimidine Synthesis Is a Metabolic Vulnerability in Triple-Negative Breast } \\
\text { Cancer. Cancer Discov. 2017;7(4):391-9. } \\
\text {-Jin U-H, Lee S-O, Pfent C, Safe S. The aryl hydrocarbon receptor ligand } \\
\text { omeprazole inhibits breast cancer cell invasion and metastasis. BMC Cancer. } \\
2014 \text { Jul 9;14:498. }\end{array}$ \\
\hline
\end{tabular}


Table S2. Preclinical references for repurposing of drugs for TNBC by ReDO DB. (continued)

\begin{tabular}{|c|c|c|c|}
\hline Losartan & Hypertension & Angiotensin receptor antagonist & 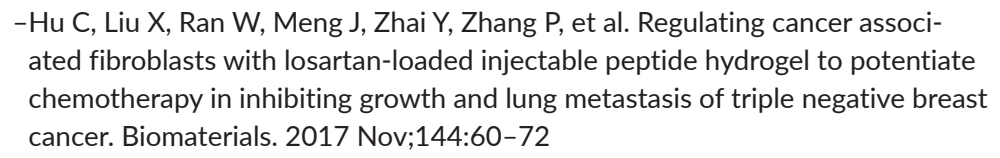 \\
\hline Lovastatin & Hyperlipidemia & HMGCR inhibitor & $\begin{array}{l}\text {-Song L, Tao X, Lin L, Chen C, Yao H, He G, et al. Cerasomal Lovastatin Nano- } \\
\text { hybrids for Efficient Inhibition of Triple-Negative Breast Cancer Stem Cells } \\
\text { To Improve Therapeutic Efficacy. ACS Appl Mater Interfaces. } 2018 \text { Feb } \\
\text { 28;10(8):7022-30 } \\
\text {-Zhang N, Liang X, Gao C, Chen M, Zhou Y, Krueger CJ, et al. Loading Lovastatin } \\
\text { into Camptothecin-Floxuridine Conjugate Nanocapsules for Enhancing Anti- } \\
\text { metastatic Efficacy of Cocktail Chemotherapy on Triple-negative Breast Cancer. } \\
\text { ACS Appl Mater Interfaces. } 2018 \text { Sep 5;10(35):29385-97. } \\
\text {-Lin Z, Zhang Z, Jiang X, Kou X, Bao Y, Liu H, et al. Mevastatin blockade of autol- } \\
\text { ysosome maturation stimulates LBH589-induced cell death in triple-negative } \\
\text { breast cancer cells. Oncotarget. } 2017 \text { Mar 14;8(11):17833-48 } \\
\text {-Koohestanimobarhan S, Salami S, Imeni V, Mohammadi Z, Bayat O. Lipophilic } \\
\text { statins antagonistically alter the major epithelial-to-mesenchymal transition sig- } \\
\text { naling pathways in breast cancer stem-like cells via inhibition of the mevalonate } \\
\text { pathway. J Cell Biochem. } 2018 \text { Sep } 6\end{array}$ \\
\hline Maraviroc & Anti-retroviral & $\begin{array}{l}\text { CC chemokine receptor antago- } \\
\text { nist }\end{array}$ & $\begin{array}{l}\text {-Norton K-A, Wallace T, Pandey NB, Popel AS. An agent-based model of triple- } \\
\text { negative breast cancer: the interplay between chemokine receptor CCR5 } \\
\text { expression, cancer stem cells, and hypoxia. BMC Syst Biol. } 2017 \text { Jul 11;11(1):68 } \\
\text {-in K, Pandey NB, Popel AS. Simultaneous blockade of IL-6 and CCL5 signaling } \\
\text { for synergistic inhibition of triple-negative breast cancer growth and metasta- } \\
\text { sis. Breast Cancer Res. } 2018 \text { 14;20(1):54. }\end{array}$ \\
\hline Mebendazole & Parasitic infection & Tubulin polymerisation inhibitor & $\begin{array}{l}\text {-Zhang L, Bochkur Dratver M, Yazal T, Dong K, Nguyen A, Yu G, et al. Meben- } \\
\text { dazole Potentiates Radiation Therapy in Triple-Negative Breast Cancer. Int J } \\
\text { Radiat Oncol Biol Phys. } 2019 \text { Jan 1;103(1):195-207 }\end{array}$ \\
\hline Melatonin & Insomnia & $\begin{array}{l}\text { Melatonin receptor agonist|nitric } \\
\text { oxide synthase inhibitor }\end{array}$ & $\begin{array}{l}\text {-Kim T-H, Cho S-G. Melatonin-induced KiSS1 expression inhibits triple-negative } \\
\text { breast cancer cell invasiveness. Oncol Lett. } 2017 \text { Aug;14(2):2511-6 } \\
\text {-Marques JHM, Mota AL, Oliveira JG, Lacerda JZ, Stefani JP, Ferreira LC, et } \\
\text { al. Melatonin restrains angiogenic factors in triple-negative breast cancer } \\
\text { by targeting miR-152-3p: In vivo and in vitro studies. Life Sci. } 2018 \text { Sep } \\
\text { 1;208:131-8 } \\
\text {-Lacerda JZ, Ferreira LC, Lopes BC, Aristizábal-Pachón AF, Bajgelman MC, Borin } \\
\text { TF, et al. Therapeutic Potential of Melatonin in the Regulation of MiR-148a-3p } \\
\text { and Angiogenic Factors in Breast Cancer. Microrna. 2019;8(3):237-47 } \\
\text {-Jardim-Perassi BV, Arbab AS, Ferreira LC, Borin TF, Varma NRS, Iskander ASM, } \\
\text { et al. Effect of melatonin on tumor growth and angiogenesis in xenograft model } \\
\text { of breast cancer. PLoS ONE. 2014;9(1):e85311 } \\
\text {-Jardim-Perassi BV, Alexandre PA, Sonehara NM, de Paula-Junior R, Reis Júnior } \\
\text { O, Fukumasu H, et al. RNA-Seq transcriptome analysis shows anti-tumor } \\
\text { actions of melatonin in a breast cancer xenograft model. Sci Rep. } 2019 \text { Jan } \\
\text { 30;9(1):966 }\end{array}$ \\
\hline
\end{tabular}


Table S2. Preclinical references for repurposing of drugs for TNBC by ReDO DB. (continued)

\begin{tabular}{|c|c|c|c|}
\hline Metformin & Diabetes & Insulin sensitizer & 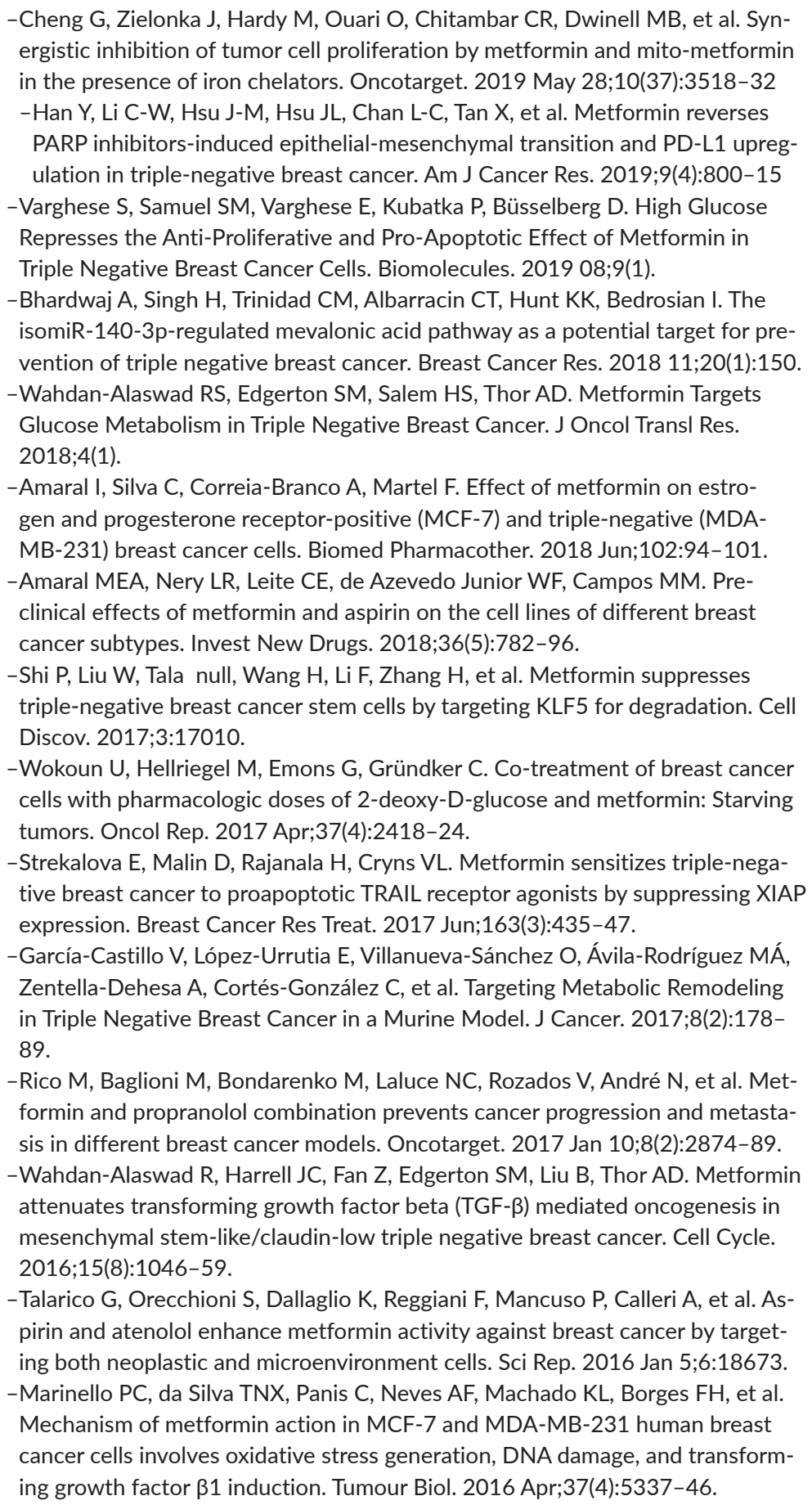 \\
\hline
\end{tabular}


Table S2. Preclinical references for repurposing of drugs for TNBC by ReDO DB. (continued)

\begin{tabular}{|c|c|c|c|}
\hline Methimazole & Hyperthyroidism & Antithyroid agent & $\begin{array}{l}\text {-Noori MS, O'Brien JD, Champa ZJ, Deosarkar SP, Lanier OL, Qi C, et al. } \\
\text { Phenylmethimazole and a thiazole derivative of phenylmethimazole inhibit IL-6 } \\
\text { expression by triple negative breast cancer cells. Eur J Pharmacol. } 2017 \text { May } \\
\text { 15;803:130-7. }\end{array}$ \\
\hline Mifepristone & Abortifacient & $\begin{array}{l}\text { Glucocorticoid receptor } \\
\text { antagonist|progesterone recep- } \\
\text { tor antagonist }\end{array}$ & $\begin{array}{l}\text {-Liu R, Shi P, Nie Z, Liang H, Zhou Z, Chen W, et al. Mifepristone Suppresses } \\
\text { Basal Triple-Negative Breast Cancer Stem Cells by Down-regulating KLF5 } \\
\text { Expression. Theranostics. 2016;6(4):533-44. } \\
\text {-Skor MN, Wonder EL, Kocherginsky M, Goyal A, Hall BA, Cai Y, et al. Glucocor- } \\
\text { ticoid receptor antagonism as a novel therapy for triple-negative breast cancer. } \\
\text { Clin Cancer Res. } 2013 \text { Nov 15;19(22):6163-72. }\end{array}$ \\
\hline Minocycline & Antibiotic & $\begin{array}{l}\text { Bacterial } 305 \text { ribosomal subunit } \\
\text { inhibitor }\end{array}$ & $\begin{array}{l}\text {-Himmel LE, Lustberg MB, DeVries AC, Poi M, Chen C-S, Kulp SK. Minocycline, a } \\
\text { putative neuroprotectant, co-administered with doxorubicin-cyclophosphamide } \\
\text { chemotherapy in a xenograft model of triple-negative breast cancer. Exp Toxi- } \\
\text { col Pathol. } 2016 \text { Oct;68(9):505-15. }\end{array}$ \\
\hline Montelukast & Allergies & Leukotriene receptor antagonist & $\begin{array}{l}\text {-Suknuntha K, Yubolphan R, Krueaprasertkul K, Srihirun S, Sibmooh N, } \\
\text { Vivithanaporn P. Leukotriene Receptor Antagonists Inhibit Mitogenic Activ- } \\
\text { ity in Triple Negative Breast Cancer Cells. Asian Pac J Cancer Prev. } 2018 \text { Mar } \\
\text { 27;19(3):833-7. }\end{array}$ \\
\hline Nelfinavir & Anti-retroviral & HIV protease inhibitor & $\begin{array}{l}\text {-Thomas S, Sharma N, Golden EB, Cho H, Agarwal P, Gaffney KJ, et al. Pref- } \\
\text { erential killing of triple-negative breast cancer cells in vitro and in vivo when } \\
\text { pharmacological aggravators of endoplasmic reticulum stress are combined } \\
\text { with autophagy inhibitors. Cancer Lett. } 2012 \text { Dec 1;325(1):63-71. }\end{array}$ \\
\hline Niclosamide & Parasitic infection & $\begin{array}{l}\text { DNA replication inhibitor|STAT } \\
\text { inhibitor }\end{array}$ & $\begin{array}{l}\text {-Yin L, Gao Y, Zhang X, Wang J, Ding D, Zhang Y, et al. Niclosamide sensitizes } \\
\text { triple-negative breast cancer cells to ionizing radiation in association with the } \\
\text { inhibition of Wnt/B-catenin signaling. Oncotarget. } 2016 \text { Jul 5;7(27):42126-38. } \\
\text {-Liu J, Chen X, Ward T, Pegram M, Shen K. Combined niclosamide with cisplatin } \\
\text { inhibits epithelial-mesenchymal transition and tumor growth in cisplatin-resis- } \\
\text { tant triple-negative breast cancer. Tumour Biol. } 2016 \text { Jul;37(7):9825-35. } \\
\text {-Lu L, Dong J, Wang L, Xia Q, Zhang D, Kim H, et al. Activation of STAT3 and } \\
\text { Bcl-2 and reduction of reactive oxygen species (ROS) promote radioresistance } \\
\text { in breast cancer and overcome of radioresistance with niclosamide. Oncogene. } \\
\text { 2018;37(39):5292-304. } \\
\text {-Pindiprolu SKSS, Chintamaneni PK, Krishnamurthy PT, Ratna Sree Ganapa- } \\
\text { thineedi K. Formulation-optimisation of solid lipid nanocarrier system of STAT3 } \\
\text { inhibitor to improve its activity in triple negative breast cancer cells. Drug Dev } \\
\text { Ind Pharm. } 2019 \text { Feb;45(2):304-13. }\end{array}$ \\
\hline Nicotinamide & $\begin{array}{l}\text { Niacin Deficiency, } \\
\text { Skin cancer che- } \\
\text { moprevention }\end{array}$ & Protein synthesis stimulant & $\begin{array}{l}\text {-Kim JY, Lee H, Woo J, Yue W, Kim K, Choi S, et al. Reconstruction of pathway } \\
\text { modification induced by nicotinamide using multi-omic network analyses in } \\
\text { triple negative breast cancer. Sci Rep. } 2017 \text { 14;7(1):3466. }\end{array}$ \\
\hline Nimodipine & Hypertension & Calcium channel blocker & $\begin{array}{l}\text {-Jin U-H, Lee S-O, Pfent C, Safe S. The aryl hydrocarbon receptor ligand } \\
\text { omeprazole inhibits breast cancer cell invasion and metastasis. BMC Cancer. } \\
2014 \text { Jul 9;14:498. }\end{array}$ \\
\hline
\end{tabular}


Table S2. Preclinical references for repurposing of drugs for TNBC by ReDO DB. (continued)

\begin{tabular}{|c|c|c|c|}
\hline Noscapine & Anti-tussive & $\begin{array}{l}\text { Bradykinin receptor } \\
\text { antagonist|tubulin polymerisa- } \\
\text { tion inhibitor }\end{array}$ & $\begin{array}{l}\text {-Doddapaneni R, Patel K, Chowdhury N, Singh M. Noscapine chemosensitiza- } \\
\text { tion enhances docetaxel anticancer activity and nanocarrier uptake in triple } \\
\text { negative breast cancer. Exp Cell Res. } 2016 \text { 01;346(1):65-73. } \\
\text {-Chougule MB, Patel AR, Jackson T, Singh M. Antitumor activity of Noscapine } \\
\text { in combination with Doxorubicin in triple negative breast cancer. PLoS ONE. } \\
2011 \text { Mar 15;6(3):e17733. } \\
\text {-Doddapaneni R, Patel K, Chowdhury N, Singh M. Reversal of drug-resistance } \\
\text { by noscapine chemo-sensitization in docetaxel resistant triple negative breast } \\
\text { cancer. Sci Rep. } 2017 \text { Nov 20;7(1):15824. }\end{array}$ \\
\hline Omega 3 & Hyperlipidemia & & $\begin{array}{l}\text {-Pizato N, Luzete BC, Kiffer LFMV, Corrêa LH, de Oliveira Santos I, Assumpção } \\
\text { JAF, et al. Omega-3 docosahexaenoic acid induces pyroptosis cell death in } \\
\text { triple-negative breast cancer cells. Sci Rep. } 2018 \text { 31;8(1):1952. } \\
\text {-Torres-Adorno AM, Vitrac H, Qi Y, Tan L, Levental KR, Fan Y-Y, et al. Eicosa- } \\
\text { pentaenoic acid in combination with EPHA2 inhibition shows efficacy in } \\
\text { preclinical models of triple-negative breast cancer by disrupting cellular } \\
\text { cholesterol efflux. Oncogene. 2019;38(12):2135-50. } \\
\text {-Pizato N, Kiffer LFMV, Luzete BC, Assumpção JAF, Correa LH, Melo HAB de, } \\
\text { et al. Omega 3-DHA and Delta-Tocotrienol Modulate Lipid Droplet Biogen- } \\
\text { esis and Lipophagy in Breast Cancer Cells: the Impact in Cancer Aggressive- } \\
\text { ness. Nutrients. } 2019 \text { May 28;11(6). } \\
\text {-Pogash TJ, El-Bayoumy K, Amin S, Gowda K, de Cicco RL, Barton M, et } \\
\text { al. Oxidized derivative of docosahexaenoic acid preferentially inhibit cell } \\
\text { proliferation in triple negative over luminal breast cancer cells. In Vitro Cell } \\
\text { Dev Biol Anim. 2015 Feb;51(2):121-7 } \\
\text {-Blanckaert V, Kerviel V, Lépinay A, Joubert-Durigneux V, Hondermarck H, } \\
\text { Chénais B. Docosahexaenoic acid inhibits the invasion of MDA-MB-231 } \\
\text { breast cancer cells through upregulation of cytokeratin-1. Int J Oncol. } \\
\text { 2015;46(6):2649-55. }\end{array}$ \\
\hline Omeprazole & Antacid & ATPase inhibitor & $\begin{array}{l}\text {-Jin U-H, Lee S-O, Pfent C, Safe S. The aryl hydrocarbon receptor ligand } \\
\text { omeprazole inhibits breast cancer cell invasion and metastasis. BMC Cancer. } \\
2014 \text { Jul 9;14:498. }\end{array}$ \\
\hline Orlistat & Obesity & Lipase inhibitor & $\begin{array}{l}\text {-Paulmurugan R, Bhethanabotla R, Mishra K, Devulapally R, Foygel K, Sekar TV, } \\
\text { et al. Folate Receptor-Targeted Polymeric Micellar Nanocarriers for Delivery } \\
\text { of Orlistat as a Repurposed Drug against Triple-Negative Breast Cancer. Mol } \\
\text { Cancer Ther. } 2016 \text { Feb;15(2):221-31 } \\
\text {-Bhargava-Shah A, Foygel K, Devulapally R, Paulmurugan R. Orlistat and } \\
\text { antisense-miRNA-loaded PLGA-PEG nanoparticles for enhanced triple negative } \\
\text { breast cancer therapy. Nanomedicine (Lond). } 2016 \text { Feb;11(3):235-47. }\end{array}$ \\
\hline Penfluridol & $\begin{array}{l}\text { Psychotic disor- } \\
\text { ders }\end{array}$ & T-type calcium channel blocker & $\begin{array}{l}\text {-Ranjan A, Gupta P, Srivastava SK. Penfluridol: An Antipsychotic Agent Sup- } \\
\text { presses Metastatic Tumor Growth in Triple-Negative Breast Cancer by Inhibit- } \\
\text { ing Integrin Signaling Axis. Cancer Res. } 2016 \text { Feb 15;76(4):877-90. }\end{array}$ \\
\hline Pentamidine & Parasitic infection & Anti-pneumocystis agent & $\begin{array}{l}\text {-Her S, Cui L, Bristow RG, Allen C. Dual Action Enhancement of Gold Nanopar- } \\
\text { ticle Radiosensitization by Pentamidine in Triple Negative Breast Cancer. Radiat } \\
\text { Res. 2016;185(5):549-62 }\end{array}$ \\
\hline
\end{tabular}


Table S2. Preclinical references for repurposing of drugs for TNBC by ReDO DB. (continued)

\begin{tabular}{|c|c|c|c|}
\hline Pentoxifylline & $\begin{array}{l}\text { Peripheral artery } \\
\text { disease }\end{array}$ & Phosphodiesterase inhibitor & $\begin{array}{l}\text {-Castellanos-Esparza YC, Wu S, Huang L, Buquet C, Shen R, Sanchez-Gonzalez } \\
\text { B, et al. Synergistic promoting effects of pentoxifylline and simvastatin on the } \\
\text { apoptosis of triple-negative MDA-MB-231 breast cancer cells. Int J Oncol. } \\
2018 \text { Apr;52(4):1246-54 }\end{array}$ \\
\hline Pirfenidone & Anti-fibrotic & TGF beta receptor inhibitor & $\begin{array}{l}\text {-Brooks D, Zimmer A, Wakefield L, Lyle LT, Difilippantonio S, Tucci FC, et al. } \\
\text { Limited fibrosis accompanies triple-negative breast cancer metastasis in } \\
\text { multiple model systems and is not a preventive target. Oncotarget. } 2018 \text { May } \\
\text { 4;9(34):23462-81. } \\
\text {-Takai K, Le A, Weaver VM, Werb Z. Targeting the cancer-associated fibro- } \\
\text { blasts as a treatment in triple-negative breast cancer. Oncotarget. } 2016 \text { Dec } \\
\text { 13;7(50):82889-901 } \\
\text {-Qi X, Yin N, Ma S, Lepp A, Tang J, Jing W, et al. p38ץ MAPK Is a Therapeutic } \\
\text { Target for Triple-Negative Breast Cancer by Stimulation of Cancer Stem-Like } \\
\text { Cell Expansion. Stem Cells. } 2015 \text { Sep;33(9):2738-47. }\end{array}$ \\
\hline Propranolol & Hypertension & Adrenergic receptor antagonist & $\begin{array}{l}\text {-Rico M, Baglioni M, Bondarenko M, Laluce NC, Rozados V, André N, et al. Met- } \\
\text { formin and propranolol combination prevents cancer progression and metasta- } \\
\text { sis in different breast cancer models. Oncotarget. } 2017 \text { Jan 10;8(2):2874-89. } \\
\text {-Choy C, Raytis JL, Smith DD, Duenas M, Neman J, Jandial R, et al. Inhibition } \\
\text { of } \beta 2 \text {-adrenergic receptor reduces triple-negative breast cancer brain metas- } \\
\text { tases: The potential benefit of perioperative } \beta \text {-blockade. Oncol Rep. } 2016 \\
\text { Jun;35(6):3135-42. } \\
\text {-Pasquier E, Ciccolini J, Carre M, Giacometti S, Fanciullino R, Pouchy C, et al. } \\
\text { Propranolol potentiates the anti-angiogenic effects and anti-tumor efficacy } \\
\text { of chemotherapy agents: implication in breast cancer treatment. Oncotarget. } \\
2011 \text { Oct;2(10):797-809. } \\
\text {-Xie W-Y, He R-H, Zhang J, He Y-J, Wan Z, Zhou C-F, et al. } \beta \text {-blockers inhibit the } \\
\text { viability of breast cancer cells by regulating the ERK/COX-2 signaling pathway } \\
\text { and the drug response is affected by ADRB2 single-nucleotide polymorphisms. } \\
\text { Oncol Rep. } 2019 \text { Jan; } 41(1): 341-50 .\end{array}$ \\
\hline $\begin{array}{l}\text { Pyrimeth- } \\
\text { amine }\end{array}$ & Parasitic infection & $\begin{array}{l}\text { Dihydrofolate reductase inhibi- } \\
\text { tor }\end{array}$ & $\begin{array}{l}\text {-Egusquiaguirre SP, Yeh JE, Walker SR, Liu S, Frank DA. The STAT3 Target Gene } \\
\text { TNFRSF1A Modulates the NF-kB Pathway in Breast Cancer Cells. Neoplasia. } \\
\text { 2018;20(5):489-98. }\end{array}$ \\
\hline Riluzole & ALS & Glutamate inhibitor & $\begin{array}{l}\text {-Speyer CL, Smith JS, Banda M, DeVries JA, Mekani T, Gorski DH. Metabotropic } \\
\text { glutamate receptor-1: a potential therapeutic target for the treatment of breast } \\
\text { cancer. Breast Cancer Res Treat. } 2012 \text { Apr;132(2):565-73. } \\
\text {-Speyer CL, Nassar MA, Hachem AH, Bukhsh MA, Jafry WS, Khansa RM, } \\
\text { et al. Riluzole mediates anti-tumor properties in breast cancer cells inde- } \\
\text { pendent of metabotropic glutamate receptor-1. Breast Cancer Res Treat. } \\
\text { 2016;157(2):217-28. } \\
\text {-Speyer CL, Bukhsh MA, Jafry WS, Sexton RE, Bandyopadhyay S, Gorski DH. } \\
\text { Riluzole synergizes with paclitaxel to inhibit cell growth and induce apoptosis in } \\
\text { triple-negative breast cancer. Breast Cancer Res Treat. } 2017 \text { Nov;166(2):407- } \\
\text { 19. }\end{array}$ \\
\hline
\end{tabular}


Table S2. Preclinical references for repurposing of drugs for TNBC by ReDO DB. (continued)

\begin{tabular}{|c|c|c|c|}
\hline Simvastatin & Hyperlipidemia & HMGCR inhibitor & 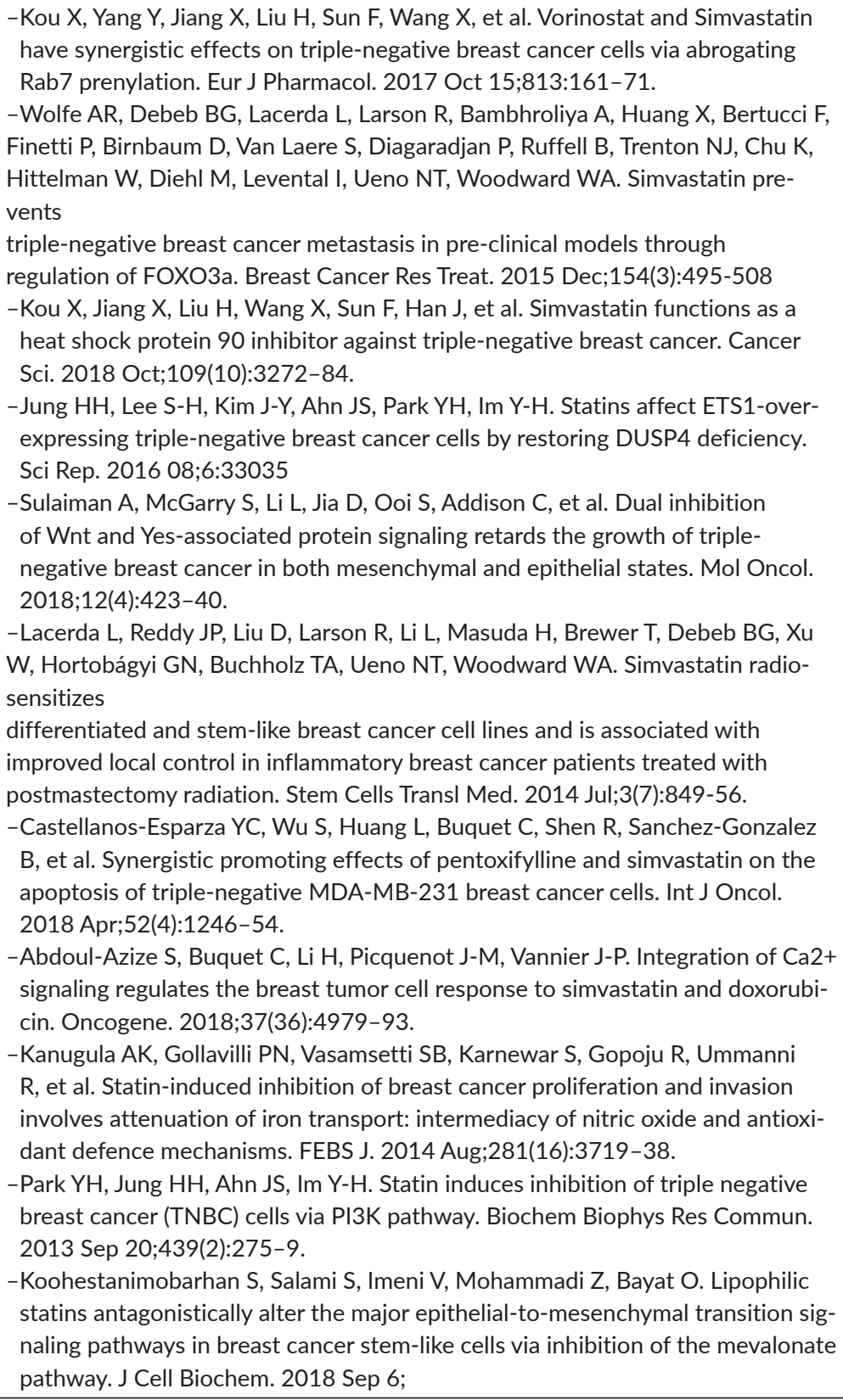 \\
\hline $\begin{array}{l}\text { Sodium Bicar- } \\
\text { bonate }\end{array}$ & $\begin{array}{l}\text { Relief of wind and } \\
\text { griping pains }\end{array}$ & & $\begin{array}{l}\text {-Abumanhal-Masarweh H, Koren L, Zinger A, Yaari Z, Krinsky N, Kaneti G, et al. } \\
\text { Sodium bicarbonate nanoparticles modulate the tumor pH and enhance the } \\
\text { cellular uptake of doxorubicin. J Control Release. } 2019 \text { Feb 28;296:1-13. }\end{array}$ \\
\hline
\end{tabular}


Table S2. Preclinical references for repurposing of drugs for TNBC by ReDO DB. (continued)

\begin{tabular}{|c|c|c|c|}
\hline Sulfasalazine & $\begin{array}{l}\text { Rheumatoid ar- } \\
\text { thritis; ulcerative } \\
\text { colitis; active } \\
\text { Crohn's Disease. }\end{array}$ & Cyclooxygenase inhibitor & $\begin{array}{l}\text {-Hasegawa M, Takahashi H, Rajabi H, Alam M, Suzuki Y, Yin L, et al. Func- } \\
\text { tional interactions of the cystine/glutamate antiporter, CD44v and MUC1-C } \\
\text { oncoprotein in triple-negative breast cancer cells. Oncotarget. } 2016 \text { Mar } \\
\text { 15;7(11):11756-69. } \\
\text {-Timmerman LA, Holton T, Yuneva M, Louie RJ, Padró M, Daemen A, et al. } \\
\text { Glutamine sensitivity analysis identifies the xCT antiporter as a common } \\
\text { triple-negative breast tumor therapeutic target. Cancer Cell. } 2013 \text { Oct } \\
\text { 14;24(4):450-65 }\end{array}$ \\
\hline Thioridazine & $\begin{array}{l}\text { Psychotic disor- } \\
\text { ders }\end{array}$ & Dopamine receptor antagonist & $\begin{array}{l}\text {-Tegowski M, Fan C, Baldwin AS. Thioridazine inhibits self-renewal in breast } \\
\text { cancer cells via DRD2-dependent STAT3 inhibition, but induces a G1 arrest } \\
\text { independent of DRD2. J Biol Chem. } 2018 \text { 12;293(41):15977-90. } \\
\text {-Goyette M-A, Cusseddu R, Elkholi I, Abu-Thuraia A, El-Hachem N, Haibe-Kains } \\
\text { B, et al. AXL knockdown gene signature reveals a drug repurposing opportunity } \\
\text { for a class of antipsychotics to reduce growth and metastasis of triple-negative } \\
\text { breast cancer. Oncotarget. } 2019 \text { Mar 12;10(21):2055-67 }\end{array}$ \\
\hline Tigecycline & Infections & $\begin{array}{l}\text { Bacterial } 30 \text { S ribosomal subunit } \\
\text { inhibitor }\end{array}$ & $\begin{array}{l}\text {-Jones RA, Robinson TJ, Liu JC, Shrestha M, Voisin V, Ju Y, et al. RB1 deficiency } \\
\text { in triple-negative breast cancer induces mitochondrial protein translation. J Clin } \\
\text { Invest. } 2016 \text { 03;126(10):3739-57 }\end{array}$ \\
\hline Tocilizumab & $\begin{array}{l}\text { Rheumatoid } \\
\text { arthritis }\end{array}$ & & $\begin{array}{l}\text {-Jin K, Pandey NB, Popel AS. Simultaneous blockade of IL-6 and CCL5 signaling } \\
\text { for synergistic inhibition of triple-negative breast cancer growth and metasta- } \\
\text { sis. Breast Cancer Res. } 2018 \text { 14;20(1):54. } \\
\text {-Weng Y-S, Tseng H-Y, Chen Y-A, Shen P-C, AI Haq AT, Chen L-M, et al. MCT-1/ } \\
\text { miR-34a/IL-6/IL-6R signaling axis promotes EMT progression, cancer stemness } \\
\text { and M2 macrophage polarization in triple-negative breast cancer. Mol Cancer. } \\
2019 \text { 18;18(1):42. }\end{array}$ \\
\hline Trifluoperazine & $\begin{array}{l}\text { Psychotic disor- } \\
\text { ders }\end{array}$ & Dopamine receptor antagonist & $\begin{array}{l}\text {-Goyette M-A, Cusseddu R, Elkholi I, Abu-Thuraia A, El-Hachem N, Haibe-Kains } \\
\text { B, et al. AXL knockdown gene signature reveals a drug repurposing opportunity } \\
\text { for a class of antipsychotics to reduce growth and metastasis of triple-negative } \\
\text { breast cancer. Oncotarget. } 2019 \text { Mar 12;10(21):2055-67. } \\
\text {-Feng Z, Xia Y, Gao T, Xu F, Lei Q, Peng C, et al. The antipsychotic agent trifluo- } \\
\text { perazine hydrochloride suppresses triple-negative breast cancer tumor growth } \\
\text { and brain metastasis by inducing G0/G1 arrest and apoptosis. Cell Death Dis. } \\
2018 \text { Sep 26;9(10):1006. } \\
\text {-Fancy RM, Kim H, Napier T, Buchsbaum DJ, Zinn KR, Song Y. Calmodulin an- } \\
\text { tagonist enhances DR5-mediated apoptotic signaling in TRA-8 resistant triple } \\
\text { negative breast cancer cells. J Cell Biochem. 2018;119(7):6216-30. } \\
\text {-Park S-H, Chung YM, Ma J, Yang Q, Berek JS, Hu MC-T. Pharmacological activa- } \\
\text { tion of FOXO3 suppresses triple-negative breast cancer in vitro and in vivo. } \\
\text { Oncotarget. } 2016 \text { Jul 5;7(27):42110-25. }\end{array}$ \\
\hline
\end{tabular}


Table S2. Preclinical references for repurposing of drugs for TNBC by ReDO DB. (continued)

\begin{tabular}{|c|c|c|c|}
\hline Valproic acid & Epilepsy & HDAC inhibitor & $\begin{array}{l}\text {-Sulaiman A, McGarry S, Lam KM, El-Sahli S, Chambers J, Kaczmarek S, et al. } \\
\text { Co-inhibition of mTORC1, HDAC and ESR1a retards the growth of triple- } \\
\text { negative breast cancer and suppresses cancer stem cells. Cell Death Dis. } 2018 \\
\text { Jul 26;9(8):815. } \\
\text {-Tarasenko N, Chekroun-Setti H, Nudelman A, Rephaeli A. Comparison of } \\
\text { the anticancer properties of a novel valproic acid prodrug to leading histone } \\
\text { deacetylase inhibitors. J Cell Biochem. 2018;119(4):3417-28 } \\
\text {-Prestegui-Martel B, Bermúdez-Lugo JA, Chávez-Blanco A, Dueñas-González A, } \\
\text { García-Sánchez JR, Pérez-González OA, et al. N-(2-hydroxyphenyl)-2-propyl- } \\
\text { pentanamide, a valproic acid aryl derivative designed in silico with improved } \\
\text { anti-proliferative activity in HeLa, rhabdomyosarcoma and breast cancer cells. J } \\
\text { Enzyme Inhib Med Chem. 2016;31(sup3):140-9 } \\
\text {-Debeb BG, Lacerda L, Larson R, Wolfe AR, Krishnamurthy S, Reuben JM, et al. } \\
\text { Histone deacetylase inhibitor-induced cancer stem cells exhibit high pentose } \\
\text { phosphate pathway metabolism. Oncotarget. 2016 May 10;7(19):28329-39 } \\
\text {-Wiegmans AP, Yap P-Y, Ward A, Lim YC, Khanna KK. Differences in Expres- } \\
\text { sion of Key DNA Damage Repair Genes after Epigenetic-Induced BRCAness } \\
\text { Dictate Synthetic Lethality with PARP1 Inhibition. Mol Cancer Ther. 2015 } \\
\text { Oct;14(10):2321-31 }\end{array}$ \\
\hline Verapamil & $\begin{array}{l}\text { Hypertension, } \\
\text { angina pectoris }\end{array}$ & Calcium channel blocker & $\begin{array}{l}\text {-Deshmukh RR, Kim S, Elghoul Y, Dou QP. P-Glycoprotein Inhibition Sensi- } \\
\text { tizes Human Breast Cancer Cells to Proteasome Inhibitors. J Cell Biochem. } \\
\text { 2017;118(5):1239-48 }\end{array}$ \\
\hline Verteporfin & $\begin{array}{l}\text { Exudative age- } \\
\text { related macular } \\
\text { degeneration }\end{array}$ & Photosensitising agent & $\begin{array}{l}\text {-Li Y, Wang S, Wei X, Zhang S, Song Z, Chen X, et al. Role of inhibitor of yes- } \\
\text { associated protein } 1 \text { in triple-negative breast cancer with taxol-based chemore- } \\
\text { sistance. Cancer Sci. } 2019 \text { Feb;110(2):561-7. } \\
\text {-Kim J, Shamul JG, Shah SR, Shin A, Lee BJ, Quinones-Hinojosa A, et al. } \\
\text { Verteporfin-Loaded Poly(ethylene glycol)-Poly(beta-amino ester)-Poly(ethylene } \\
\text { glycol) Triblock Micelles for Cancer Therapy. Biomacromolecules. } 2018 \\
\text { 13;19(8):3361-70 } \\
\text {-Andrade D, Mehta M, Griffith J, Panneerselvam J, Srivastava A, Kim T-D, et al. } \\
\text { YAP1 inhibition radiosensitizes triple negative breast cancer cells by targeting } \\
\text { the DNA damage response and cell survival pathways. Oncotarget. } 2017 \text { Nov } \\
\text { 17;8(58):98495-508 }\end{array}$ \\
\hline Warfarin & $\begin{array}{l}\text { Prophylaxis of } \\
\text { systemic embo- } \\
\text { lism, of venous } \\
\text { thrombosis and } \\
\text { pulmonary embo- } \\
\text { lism. }\end{array}$ & Vitamin $\mathrm{K}$ antagonist & $\begin{array}{l}\text {-Beaudin S, Kokabee L, Welsh J. Divergent effects of vitamins K1 and K2 on } \\
\text { triple negative breast cancer cells. Oncotarget. } 2019 \text { Mar 19;10(23):2292-305 }\end{array}$ \\
\hline
\end{tabular}


Table S2. Preclinical references for repurposing of drugs for TNBC by ReDO DB. (continued)

\begin{tabular}{|c|c|c|c|}
\hline $\begin{array}{l}\text { Zoledronic } \\
\text { acid }\end{array}$ & $\begin{array}{l}\text { Osteoporosis, } \\
\text { prophylaxis of } \\
\text { skeletal frac- } \\
\text { tures and treat } \\
\text { hypercalcemia of } \\
\text { malignancy, treat } \\
\text { pain from bone } \\
\text { metastases }\end{array}$ & Bone resorption inhibitor & $\begin{array}{l}\text {-Liu H, Wang S-H, Chen S-C, Chen C-Y, Lin T-M. Zoledronic acid blocks the } \\
\text { interaction between breast cancer cells and regulatory T-cells. BMC Cancer. } \\
2019 \text { Feb 26;19(1):176. } \\
\text {-Cai X-J, Wang Z, Cao J-W, Ni J-J, Xu Y-Y, Yao J, et al. Anti-angiogenic and anti- } \\
\text { tumor effects of metronomic use of novel liposomal zoledronic acid depletes } \\
\text { tumor-associated macrophages in triple negative breast cancer. Oncotarget. } \\
2017 \text { Oct 13;8(48):84248-57 } \\
\text {-Schech AJ, Kazi AA, Gilani RA, Brodie AH. Zoledronic acid reverses the } \\
\text { epithelial-mesenchymal transition and inhibits self-renewal of breast cancer } \\
\text { cells through inactivation of NF-kB. Mol Cancer Ther. } 2013 \text { Jul;12(7):1356-66 } \\
\text {-Ibrahim T, Liverani C, Mercatali L, Sacanna E, Zanoni M, Fabbri F, et al. Cisplatin } \\
\text { in combination with zoledronic acid: a synergistic effect in triple-negative } \\
\text { breast cancer cell lines. Int J Oncol. } 2013 \text { Apr;42(4):1263-70 } \\
\text {-lbrahim T, Mercatali L, Sacanna E, Tesei A, Carloni S, Ulivi P, et al. Inhibition of } \\
\text { breast cancer cell proliferation in repeated and non-repeated treatment with } \\
\text { zoledronic acid. Cancer Cell Int. 2012 Nov 22;12(1):48. } \\
\text {-Gschwantler-Kaulich D, Weingartshofer S, Grunt TW, Mairhofer M, Tan Y, } \\
\text { Gamper J, et al. Estradiol impairs the antiproliferative and proapoptotic effect } \\
\text { of Zoledronic acid in hormone sensitive breast cancer cells in vitro. PLoS ONE. } \\
\text { 2017;12(9):e0185566 } \\
\text {-Tripathi R, Singh P, Singh A, Chagtoo M, Khan S, Tiwari S, et al. Zoledronate and } \\
\text { Molecular lodine Cause Synergistic Cell Death in Triple Negative Breast Cancer } \\
\text { through Endoplasmic Reticulum Stress. Nutr Cancer. 2016 Jun;68(4):679-88. }\end{array}$ \\
\hline
\end{tabular}

